Article

\title{
Relationship between Sustainable Management Activities and Financial Performance: Mediating Effects of Non-Financial Performance and Moderating Effects of Institutional Environment
}

\author{
Yuhan Liu (D), Choo Yeon Kim (D), Eun Hwa Lee and Jae Wook Yoo * \\ College of Business Administration, Konkuk University, Seoul 05029, Korea; han31@konkuk.ac.kr (Y.L.); \\ chookim@konkuk.ac.kr (C.Y.K.); tobejjan@konkuk.ac.kr (E.H.L.) \\ * Correspondence: jwyoo@konkuk.ac.kr
}

check for updates

Citation: Liu, Y.; Kim, C.Y.; Lee, E.H.; Yoo, J.W. Relationship between Sustainable Management Activities and Financial Performance:

Mediating Effects of Non-Financial Performance and Moderating Effects of Institutional Environment. Sustainability 2022, 14, 1168.

https://doi.org/10.3390/su14031168

Academic Editors: JinHyo Joseph Yun, JungHyun Yoon, Wookjoon Sung, Yuri Sadoi and Valentina Della Corte

Received: 14 December 2021

Accepted: 13 January 2022

Published: 20 January 2022

Publisher's Note: MDPI stays neutral with regard to jurisdictional claims in published maps and institutional affiliations.

Copyright: () 2022 by the authors. Licensee MDPI, Basel, Switzerland. This article is an open access article distributed under the terms and conditions of the Creative Commons Attribution (CC BY) license (https:// creativecommons.org/licenses/by/ $4.0 /)$.

\begin{abstract}
The importance of corporate responsibility for society and environments is emphasized by increasing influence of firms on various stakeholders. Firms strengthen environmental, social, and governance (ESG) activities, which are critical elements for sustainable management. However, there are inconsistent findings on the relationship between ESG activities and firms' financial performance in prior studies because of the lack of full consideration of internal mechanisms and external conditions. To overcome this limitation, this study investigates the mediating effect of non-financial performance and the moderating effect of the institutional environment on the relationship between firms' ESG activities and their financial performance in a unified moderated mediation model. Samples for empirical analyses were collected by a survey from 304 small and medium-sized Chinese manufacturers. The results of a mediation analysis reveal that each ESG activity has a positive effect on firms' financial performance, and the impact of ESG activities on financial performance is completely mediated by non-financial performance. The results of a moderated mediation analysis further indicate that the mediating effect varies depending on the level of institutional pressure from the government, consumers, and competitors. The study suggests the need for interdisciplinary research in sustainable management and institutional theory and emphasizes the importance of sustainable management for performance improvement in a changing environment.
\end{abstract}

Keywords: sustainable management; ESG activities; institutional environment; non-financial performance; financial performance

\section{Introduction}

An increase in environmental problems, such as global warming and water pollution, and social problems, including poverty, human rights violations, and wealth inequality, gives firms significant responsibilities vis-à-vis the environment and society [1,2]. Thus, a firm's fulfillment of environment- and society-related responsibilities has become an essential criterion to determine its sustainability [1]. Amid these changes, studies in the field of sustainability have steadily increased. Although prior studies have contributed to the theoretical development of sustainable management $[3,4]$, the empirical findings in the sustainable management activities-financial performance relationships seem to be rather inconsistent and even conflicting, as presented in Appendix A [5-18]. For example, Velte [6], Huang [7], and Friede et al. [12] have demonstrated a positive effect of ESG activities on firm performance, whereas Zhao et al. [13] have shown no significant effect of ESG activities on firms' return on capital employed (ROCE). Even worse, Duque-Grisales [17] and Ruan [18] have demonstrated a negative influence of ESG activities on firm performance.

Such inconsistencies in prior studies point out the need for identifying critical mediating and moderating variables that affect the relationships between ESG activities and 
performance. However, little empirical research has been conducted on the specific pathways through which firms' sustainable management activities have a positive impact on their financial performance or conditions under which the effectiveness of sustainable management activities is strengthened. In addition, although firms' sustainable management activities are carried out across various areas such as environment, social, and governance, prior studies have mainly focused on the effect of comprehensive implementation level of sustainable management activities relying on secondary data, such as sustainability reports $[5,10,19]$. This might be another reason for inconsistencies found in prior studies. Lastly, prior research findings have been applied indiscriminately in the context of both advanced and emerging economies although most prior studies were performed based on samples from firms in advanced countries. The political, economic, social, cultural, and institutional systems in developing countries differ from those in advanced countries. Thus, applying the results of prior studies to the firms in emerging countries can create problems in practice. Therefore, further research is needed on the firms in emerging countries.

Until 2010, most Chinese firms did not disclose information on their governance, environmental management, and social responsibility activities [20]. However, owing to economic policies driven by economic growth, salient issues such as environmental pollution, economic inequality, and employment problems have been increasing in China. Consequently, the importance of corporate social responsibility (CSR) and sustainable management has begun to be emphasized in recent years [21]. CSR was stipulated for the first time in the amended bill in 2006, and since then, the interest in corporate sustainability has steadily increased [13]. Moreover, on 21 December 2015, the Hong Kong Stock Exchange revised its "ESG Reporting Guidelines" by adding a "Comply or Explain" clause. This clause requires listed firms to disclose their ESG information or explain the reasons for its non-disclosure [13]. In 2018, the Shanghai Stock Exchange also established guidelines for information disclosure regarding listed firms' ESG activities [11]. Such institutional changes have greatly increased the interest of Chinese firms and society in ESG activities.

In addition, firms in China have seriously considered the relative cost, efficiency, and various risk factors that may arise from changes in the institutional environment since the transition from a planned economy to a market economy system through "opening and reform" policy of the government in 1978 [22,23]. As an inherent feature of a business, institutional environments impact the relationship between firms' strategic actions and performances. However, there are few studies on the effects of various types of institutional pressures on the relationship between firms' sustainable management activities and performance $[24,25]$.

To overcome the limitations of previous studies and bridge the gap between research and practice, this study focused on answering the following three questions: (1) whether, (2) through what mechanisms (mediation), and (3) under what conditions firms' ESG activities have a positive impact on their financial performance in a unified moderated mediation model.

Samples for empirical analysis were collected through a survey from small and medium-sized manufacturing firms in China where ESG activities were autonomously conducted in comparison to large firms. Based on 304 Chinese firms, this study first examined whether their ESG activities have a positive relationship with financial performance. According to stakeholder theory and legitimacy theory, sustainable management activities enhance stakeholders' perception of corporate social responsibility, corporate image, and brand value, which in turn increase firms' financial performance [26]. Based on these theoretical perspectives, this study investigates the role of non-financial performance, measured by employee satisfaction level, stakeholder satisfaction level, external image, social reputation, and the brand value, as a mediator that links a relationship between ESG activities and financial performance.

Finally, this study further examined the moderating effect of the institutional environments on the relationship of ESG activities-non-financial performance-financial performance to understand how the effect of firms' ESG activities on financial performance 
through non-financial performance varies depending on institutional pressure levels (moderated mediation). The moderated mediation model is based on institutional theory that argues for the effects of various institutional environments on the relationship between corporate decision-making or activities and their performance.

From an integrated perspective of stakeholder theory, legitimacy theory, and institutional theory, this study contributes to overcoming the limitations of prior studies by providing academic implications for the role of non-financial performance and institutional environments in explaining the relationship between firms' ESG activities and their financial performance. It also provides practical implications to maximize firms' performance through ESG activities, which are becoming increasingly important. With the findings of this study, firms will be able to plan and implement ESG activities more effectively to improve performance and enhance sustainability.

The rest of the paper consists of the following: The next section reviews and discusses the theoretical background of the study. The following section proposes research models and hypotheses on the relationship between ESG activities, non-financial performance, institutional environment, and financial performance. Then, the methodology for empirical analyses and the results of the analyses are fully explained. Finally, the conclusion provides theoretical and practical implications. It also proposes research limitations and potential future research to overcome them.

\section{Theoretical Background}

\subsection{Concept of Sustainable Management}

Profit is the primary and essential factor for a firm's survival. However, corporate activities that focus only on improving short-term financial performance have been a major cause of environmental pollution and social problems. In the report, "Limits to Growth" [27], sustainability emerged as a common global task for solving the environmental pollution problem caused by rapid industrialization. Since then, the “UN's Environmentally Sound and Sustainable Development" concept has been presented as a comprehensive normative system to achieve sustainability. The "Global Reporting Initiative (GRI) Standard," a global standard in the economic, environmental, and social sectors for sustainable management has been established. Sustainable management has emerged as a common concern for all countries and firms worldwide.

The concept of sustainable management is generally defined in three dimensions. The first is the definition from the triple bottom line (TBL) perspective [28]. In the TBL concept presented by Elkington [28], "economic performance" (productivity increase, added value creation, job creation, profitability, and fair trade), "environmental sound" (eco-friendly production, pollutants, greenhouse gases, resource conservation, and harmful substances reduction), and "social responsibility" (social contribution, product responsibility, human rights, and labor) are presented as three fundamental pillars for sustainable management. These factors have been used to derive key indicators to evaluate corporate sustainable management [29]. The second is a definition from a stakeholder-centered perspective. From this viewpoint, sustainable management is defined as business activities conducted to strengthen communication with stakeholders, realize economic benefits, and achieve environmental and social soundness to secure the continuity of corporate management [30]. The third is a definition from a management performance perspective, wherefrom sustainable management is defined as business activities that create shareholder value from a long-term perspective by accommodating opportunities derived from economic, environmental, and social development processes and managing risks [31,32].

As observed through the definitions of the three aforementioned perspectives, sustainable management is fundamentally based on the interests of stakeholders, who have direct or indirect relationships with the business activities of a firm. A firm should accept the needs and interests of various stakeholders and ultimately reflect them systematically in its management activities for sustainable growth [33]. The ESG framework is primarily 
used for corporate sustainability evaluations. Here, a firm's sustainability is evaluated by categorizing it into three areas [34].

\subsection{Legitimacy Theory, Stakeholder Theory, and Institutional Theory}

A firm is motivated to communicate with internal and external stakeholders to adapt to the changing environment and take advantage of opportunities $[19,35]$. This process can be explained within the ambits of the "legitimacy," "stakeholder," and "institutional" theories [36]. The legitimacy theory assumes that a "social contract" exists between the firm and society. Through this contract, society provides various resources to the firm. It is an essential factor for the sustainable growth and survival of the firm. Contrary, a firm provides the goods and services necessary for society $[37,38]$. If it does not comply with the "social contract," its cost of capital may increase, and resource acquisition may become difficult. Furthermore, the firm may face various sanctions from regulatory bodies, which may even threaten its existence [39].

In the stakeholder theory, stakeholders are defined as a "group with the power to participate in decision-making in management activities." A firm has the motivation to efficiently manage relationships among various stakeholders on an ethical basis for value creation [40]. A firm can manage its relationships with stakeholders in the ethical/normative branch by emphasizing social responsibility, and the managerial/pragmatic/strategic branch, where stakeholders are classified and managed according to their importance to enhance the practicality of corporate management [41]. Furthermore, the impact of stakeholders on the firm can be managed by classifying them into "primary" and "secondary" stakeholders [40].

Finally, the institutional theory defines an institutional environment as "an environment containing regulatory mechanisms that create unique participants and action procedures as a common system containing representative and normative rules" [42]. Certain organizations, such as government, public opinion, and media, are typical institutional environments [43]. The institutional environment creates a set of implicit or explicit rules in several areas, such as organizational structure and behavior. They become the basic requirements for members within that institutional field [44]. Compliance with these expectations and norms is essential for firms to gain legitimacy in their environment and enhance their accessibility to critical resources [45].

Studies have argued that firms can adopt common goals, structures, and systems to achieve social justification and have classified this process into coercive, normative, and imitative isomorphism $[42,46]$. Coercive isomorphism stems from "formal and informal pressure exerted by other organizations" [46]. Pressure from government agencies through policies or regulations is a representative example [47]. Imitative isomorphism occurs when an organization imitates another firm in response to uncertainty [46]. Uncertainty about efficient or effective behavior promotes a firm's imitative isomorphism [48]. Normative isomorphism urges a firm to be perceived as performing legitimate organizational activities [46]. It usually stems from the values and standards of behavior recommended by external stakeholders that are mainly related to consumers $[46,48,49]$. The institutional theory argues that firms' decisions and actions are driven by legitimacy issues, which lead to institutional isomorphism [46]. Long-term stability and survival can be guaranteed for firms that meet institutional needs [50].

The legitimacy, stakeholder, and institutional theories exhibit a system-oriented characteristic that focuses on the firm's connection and environment [36]. Furthermore, they explain a phenomenon based on "adaptation" to a specific aspect. Specifically, the legitimacy theory emphasizes the adaptation of organizational operations to a social contract, the stakeholder theory concentrates on the adaptation to the requirements of stakeholder groups, and the institutional theory highlights the adaptation to regulations and norms [38,42,46].

\subsection{Firms' Performance}

Creating economic performance is essential for a firm to gain a competitive advantage and survive [33]. Thus, to date, many studies have regarded "economic performance 
and profit creation" as essential criteria toward determining sustainability [26]. Economic performance can be measured by financial performance, in terms of profit, productivity, market share, sales, return on assets, return on equity, and return on investment [51,52]. Financial performance, which can be measured in monetary and quantitative units [53], has been adopted in many studies because it helps to assess the performance level and status of a firm.

However, the importance of performance evaluation from a more comprehensive and firm-wide perspective that can reflect the strategy and vision of the firm has been emphasized with the increasing significance of market change and sustainable management [54]. Thus, a firm's performance measurement should include financial and non-financial factors [55,56], especially as many financial indicators have been reported to be unlinked to a firm's long-term growth strategy and are inappropriate for measuring future value [54]. Non-financial performance consists of indicators such as customer satisfaction, corporate image, and new product adoption rate. It can be measured by evaluating the process and qualitative factors of business activities $[57,58]$.

Information on financial performance is insufficient to evaluate future uncertainties caused by changes in the business environment and the possibility of attaining corporate sustainability. Therefore, the evaluation of non-financial performance is vital. Regarding the relationship between financial and non-financial performance, Hoque [59] asserts that firms creating success factors through the measurement of non-financial performance exhibit higher financial performance. Moreover, many studies argue that some firms' business activities affect financial performance through non-financial performance [60]. Thus, in many cases, non-financial performance plays a role in mediating the impact of corporate strategy on financial performance [61].

\section{Research Hypotheses}

\subsection{Relationship between ESG Activities and Financial Performance}

The ESG activities of firms for sustainable management have become an essential competitive tool to secure competitiveness in the changing global business environment [32]. However, many controversies remain about whether a firm can improve its financial performance through ESG activities [4,62]. Studies have reported inconsistent results in this regard [63]. Scholars attribute it to the fact that they analyze the effects by measuring only the activities of a specific ESG sector for sustainable management or measuring multiple activities together without distinction [64]. For example, measuring social activities is helpful for a specific firm's financial performance. However, when the effect of environmental activities is negative, the overall effect of the firm's ESG activities may take various forms, including positive (whereby the effect size of social activities is larger than that of environmental activities), negative (whereby the effect size of environmental activities is larger than that of social activities), or no effect (whereby the effect size of environmental activities is similar to that of social activities). Therefore, this study subdivides the activities for sustainability management into ESG activities and presents and analyzes the hypotheses for the effect of each activity on financial performance.

First, concerning the impact of corporate environmental activities on financial performance, the activities performed by a firm in response to environmental regulations have become an opportunity to improve performance, unlike in the past [65]. A firm can reduce costs through business operations that comply with environmental regulations [66], reduce exposure to risk [67], and improve performance through eco-friendly business opportunities [68]. Recently, environmental problems caused by firms, such as greenhouse gas emissions, water quality, and air pollution, have received worldwide attention. Many countries have established policies to address these issues [69]. The Chinese President, Xi Jinping, announced the goal of achieving carbon neutrality by 2060 at the UN General Assembly held in October 2020. At the 5th plenary session of the 19th Central Committee of the Communist Party of China held in December, the development of green finance by strengthening the laws and policies that promote green growth through the "14th Five-Year 
Plan for National Economic and Social Development and Recommendation for Long-Term Goals for 2035" was addressed. This move is geared to achieve the reform of green technology and presented various environmental regulations, including the establishment and operation of the eco-friendly remodeling of the industry and the trading system for carbon credits and pollutants. In addition, the policies operate a nationwide carbon emission trading system by establishing and implementing the "National Carbon Emission Trading Market Construction Plan".

These changes suggest that Chinese firms that actively respond to environmental issues can seize opportunities for long-term development and sustainability. Environmental pollution refers to the waste of resources, energy, and materials. Firms that eliminate these wastes will be able to create additional value by using capital, technology, and resources more efficiently. In other words, the environmental activities of a firm can be an essential factor in reducing the cost of inefficiency and strengthening the firm's ability to capture and utilize new business opportunities [70]. From this perspective, the performance of Chinese firms that strictly comply with environmental standards and actively engage in environmental activities is set to improve [71], while that of firms that do not actively respond to environmental issues may decline [72]. Thus, the following hypothesis is established for the relationship between environmental activities and the financial performance of Chinese firms:

Hypothesis 1-1. Environmental activities have a positive relationship with financial performance.

A firm must bear the human and financial costs for communication with various stakeholders. However, the financial benefits of stakeholder management are likely to outweigh the costs. In this regard, a few empirical studies have suggested that firms that communicate with various internal and external stakeholders based on social activities and systematically manage their interests achieve high financial performance [40].

Recently, interest in the social responsibility activities of Chinese firms has been continuously increasing. In 2015, three social responsibility manuals, including Guidelines for Social Responsibility (GB/T 36000-2015), Guidelines for Compilation of Social Responsibility Reporting (GB/T 36001 2015), and Guidelines for Classification of Social Responsibility (GB/T 36002-2015) were jointly compiled by the China Institute for Standardization. Accordingly, from January 2016, the Chinese government mandated all firms operating in China to fulfill their social responsibilities according to the unified standards. Moreover, it promoted CSR activities by adopting international standards, such as [21] Social Accountability International's SA8000, International Standardization Organization's ISO 26000, and GRI's G4 [21]. The government required firms to prepare a report on social responsibility to promote a harmonious society, scientific view of development, sustainable development, and social responsibility [21]. In addition, the State Council of China announced the "135 Poverty Resolution Plan" to solve the poverty problem in November 2016. This strategy was established under the China 2030 Sustainable Development Agenda Action Plan announced by the Chinese government in September 2015 [33].

According to the resource-based view, CSR activities can be an essential foundation to form a competitive advantage, which is difficult to imitate [66] and a key element of corporate strategy [73]. In terms of social activities, performing activities that comply with laws and regulations related to social values and ethical business management activities can engender a positive impact, eventually improving financial performance [74]. Accordingly, the following hypothesis is established for the relationship between social activities and the financial performance of Chinese firms.

Hypothesis 1-2. Social activities have a positive relationship with financial performance.

Corporate governance refers to a mechanism that monitors and controls the overall management process of a firm, such as the procurement and utilization of management resources and distribution of profits [75]. Weak corporate governance deteriorates corporate 
profitability and value [76], while transparent and fair governance enables firms to generate stable profits and improve performance [77].

China's Securities and Exchange Commission required all listed firms to disclose their corporate governance information by amending the "Guidelines for Corporate Governance of Listed Firms" to build trusting relationships with various stakeholders, including investors [18,78]. Thus, Chinese firms seek to hire independent auditors, add outside directors, and strengthen information disclosure to build trusting relationships with stakeholders. They also disclose information related to the structure of the board of directors, audit procedures, and shareholder rights $[18,78]$. Such activities can increase transparency, enhance resource utilization, attract investment capital, and boost investor confidence [75]. Thus, the following hypothesis on the relationship between corporate governance activities and the financial performance of Chinese firms is established.

Hypothesis 1-3. Governance activities have a positive relationship with financial performance.

\subsection{Relationship among ESG Activities, Non-Financial Performance, and Financial Performance}

Financial and non-financial performance based on the realization of environmental and social values are essential to ensure sustainability [79]. Here, non-financial performance can be evaluated by stakeholder satisfaction, brand value, social reputation, and firm image [80]. The United Nations Environment Program Finance Initiative presented ecofriendly activities, social contributions, and transparent governance that could significantly impact non-financial performance as key factors to consider when making an investment decision for a firm. This proposal became the basis for the UN Principles for Responsible Investment. Thus, a firm's ESG activities are a critical factor to be recognized for its legitimacy by various internal and external stakeholders and to receive the necessary resources for sustainable growth [26]. A firm can improve its image and reputation through its ESG activities [26]. In other words, when a firm protects the environment and promotes the growth and prosperity of future generations, the firm's reputation can be enhanced [63]. The firm's reputation thus relies on the stakeholders' perceptions of the firm. A firm's environmental and social activities are found to be beneficial in areas, such as reducing taxes, reducing operational risks, improving the ability to win favorable contracts, retaining consumers, and maintaining a favorable reputation [63].

Recently, even in China, environmental pollution caused by rapid industrialization has increased the interest of the community in corporate activities [13]. Furthermore, the Firms Act amended in 2006 expanded the scope of stakeholders, and the economic inequality and human rights issues caused by rapid economic growth strengthened stakeholders' CSR perceptions [21]. Finally, governance activities are key factors that can significantly impact stakeholders' perceptions and image formation of the firm. Transparent governance can help to build a good social image and reputation and enhance employee satisfaction and loyalty [35]. Thus, the Chinese government issued a code to protect stakeholders' interests, including shareholders, banks, other creditors, employees or suppliers, and the community and other stakeholders [81]. As an emerging market, the degree of development of the capital market and the external supervision system has not reached a mature stage, but these changes are strengthening the activities of Chinese firms, which aim to improve their governance and improve their image and reputation [18]. Accordingly, the following hypotheses on the relationship between ESG activities and the non-financial performance of Chinese firms are established:

Hypothesis 2-1. Environmental activities have a positive relationship with non-financial performance.

Hypothesis 2-2. Social activities have a positive relationship with non-financial performance.

Hypothesis 2-3. Governance activities have a positive relationship with non-financial performance. 


\subsection{Relationship between Non-Financial Performance and Financial Performance}

Concerning hitherto research on the relationship between a firm's financial and nonfinancial performance, more studies claim a positive relationship than a negative one between both variables [82]. Studies that argue that non-financial performance can positively affect financial performance ground their claims on the stakeholder theory [83]. According to this theory, a good image and reputation of stakeholders can create loyal customers for the firm's products and services, which serve to enhance the firm's value [82]. In other words, firms can secure a competitive advantage and improve their financial performance by strengthening trusting relationships with stakeholders [84]. Accordingly, the following hypothesis on the relationship between the non-financial and financial performance of Chinese firms is established:

Hypothesis 3. Non-financial performance has a positive relationship with financial performance.

\subsection{Mediating Effect of Non-Financial Performance on the Relationship between ESG Activities and Financial Performance}

By protecting stakeholders' interests through sustainable management activities, a firm can improve its reputation and increase its chances of long-term survival. Furthermore, a positive corporate reputation can create loyal customers for a firm's products and services, which can help to improve the firm's value [82,85]. Corporate activities in each field of ESG can reduce the risk of information asymmetry and wrong choices, thus serving as a signal provided by the firm, including useful information for stakeholders to make accurate decisions [11]. ESG activities imply that a firm can be more stable and resilient in longterm operations and finance [86]. A firm can receive support from the local community and consumers through responsible management activities consistent with environmental soundness and social issues, thus promoting stable management activities and corporate value [13]. Moreover, by establishing a transparent governance structure, it can effectively manage the conflicts of interest, which can occur between various stakeholders, and risks of regulations, thus increasing the efficiency of business operations and the return on capital owing to the investor preference effect [65].

Stakeholders are agents of social control [87]. Thus, a firm can enhance its image and reputation by meeting stakeholders' needs. Furthermore, efforts to improve a firm's non-financial performance can help to enhance its financial performance by alleviating potential conflicts between society and the firm and reducing related costs [88]. Accordingly, the following hypotheses on the relationship between ESG activities, non-financial performance, and financial performance of Chinese firms are established:

Hypothesis 4-1. Non-financial performance mediates the positive relationship between environmental activities and financial performance.

Hypothesis 4-2. Non-financial performance mediates the positive relationship between social activities and financial performance.

Hypothesis 4-3. Non-financial performance mediates the positive relationship between governance activities and financial performance.

\subsection{Moderated Mediating Effect of the Institutional Environment}

According to the institutional theory, a firm must acquire social legitimacy for its existence value [48]. A firm is dependent on external resources, especially as it is difficult for a firm to be self-sufficient with all the resources necessary for its operation [89]. A firm that effectively responds to institutional pressure and complies with norms and rules can more easily obtain the external resources necessary for survival and growth by securing social legitimacy. Accordingly, for smooth and stable operations, the firm needs to respond to institutional pressure [90], the level of which influences the firm's strategic choices and 
effectiveness [72]. For example, the firm needs to strengthen ESG activities to respond to stakeholder pressure [45]. However, the level of ESG activities conducted by the firm and its impact on performance may vary depending on the level of institutional pressure on ESG activities. Thus, there is a need to examine the effect of each type of institutional pressure [48], which can be divided into coercive, normative, and imitative, on performance through interaction with the firm's ESG activities.

First, coercive pressure is defined as "the formal or informal pressure generated by the institutions and regulations of the society to which the firm belongs" [46]. Coercive pressure arising from the influence exerted by those in power, such as regulation by government agencies, can shape standards for corporate behavior and encourage firms to adopt or reinforce certain behaviors [48]. In this regard, the government's ESG-related policies and regulations act as coercive pressure on firms and affect social demands and expectations for sustainable activities. Accordingly, they strengthen the impact of ESG activities on the firm's reputation, image, and brand value, and, thus, on financial performance [49]. Thus, the following hypotheses are established for the moderating effect of coercive government pressure on the relationship between the ESG activities, non-financial performance, and financial performance of Chinese firms:

Hypothesis 5-1. The positive relationship between firms' environmental activities and financial performance through non-financial performance is stronger in the presence of higher levels of coercive pressure.

Hypothesis 5-2. The positive relationship between firms' social activities and financial performance through non-financial performance is stronger in the presence of higher levels of coercive pressure.

Hypothesis 5-3. The positive relationship between firms' governance activities and financial performance through non-financial performance is stronger in the presence of higher levels of coercive pressure.

Mimetic pressure refers to the pressure to imitate a competitor's behavior, which is determined to be successful. A firm that adapts to mimetic pressure is more likely to protect itself from potential losses and gain legitimacy for decision-making. Thus, it imitates leading competitors to secure social legitimacy and legitimacy for decision-making [46,91]. From this perspective, a firm's ESG activities emulate the behavior of an organization, which is recognized as successful by stakeholders among those structurally similar to their organization [91]. For instance, manufacturers tend to imitate their competitors in terms of managing extended supply chain activities to achieve carbon emission reduction targets for sustainable management. This measure can improve corporate performance by strengthening the legality and legitimacy of corporate activities [92]. Thus, the demand and expectation of replicating the superior ESG activities of competitors can strengthen the impact of a firm's ESG activities on the reputation, image, and brand value, and, ultimately, financial performance [93]. Accordingly, the following hypotheses are established on the moderating effect of mimetic pressure on the relationship between the ESG activities, non-financial performance, and financial performance of Chinese firms:

Hypothesis 6-1. The positive relationship between firms' environmental activities and financial performance through non-financial performance is stronger in the presence of higher levels of mimetic pressure.

Hypothesis 6-2. The positive relationship between firms' social activities and financial performance through non-financial performance is stronger in the presence of higher levels of mimetic pressure.

Hypothesis 6-3. The positive relationship between firms' governance activities and financial performance through non-financial performance is stronger in the presence of higher levels of mimetic pressure. 
Normative pressure arises from the values and standards of behavior recommended and expected by external stakeholders [48]. A firm must understand and comply with the standards, norms, and expectations of external stakeholders to achieve social legitimacy. In particular, customer demand forms a critical normative pressure [93], which can be an important driving force for a firm to reinforce certain activities [48]. For instance, the positive perception that consumers have for a firm's eco-friendly products and socially responsible activities can change the decision-making and behavior of the firm by acting as normative pressure [47]. In addition, by reinforcing consumers' value on corporate activities, the impact of corporate activities on the reputation, image, and brand value, and, ultimately, financial performance, can be strengthened [94]. Thus, the following hypotheses are established on the moderating effect of normative pressure on the relationship between the ESG activities, non-financial performance, and financial performance of Chinese firms:

Hypothesis 7-1. The positive relationship between firms' environmental activities and financial performance through non-financial performance is stronger in the presence of higher levels of normative pressure.

Hypothesis 7-2. The positive relationship between firms' social activities and financial performance through non-financial performance is stronger in the presence of higher levels of normative pressure.

Hypothesis 7-3. The positive relationship between firms' governance activities and financial performance through non-financial performance is stronger in the presence of higher levels of normative pressure.

The research model for the presented hypothesis is shown in Figure 1. The causal relationships of ESG activities-nonfinancial performance-financial performance hereto rely on legitimacy and stakeholder theories, while the moderating effect of the institutional environment on the ESG activities-nonfinancial performance-financial performance relationships are based on institutional theory.

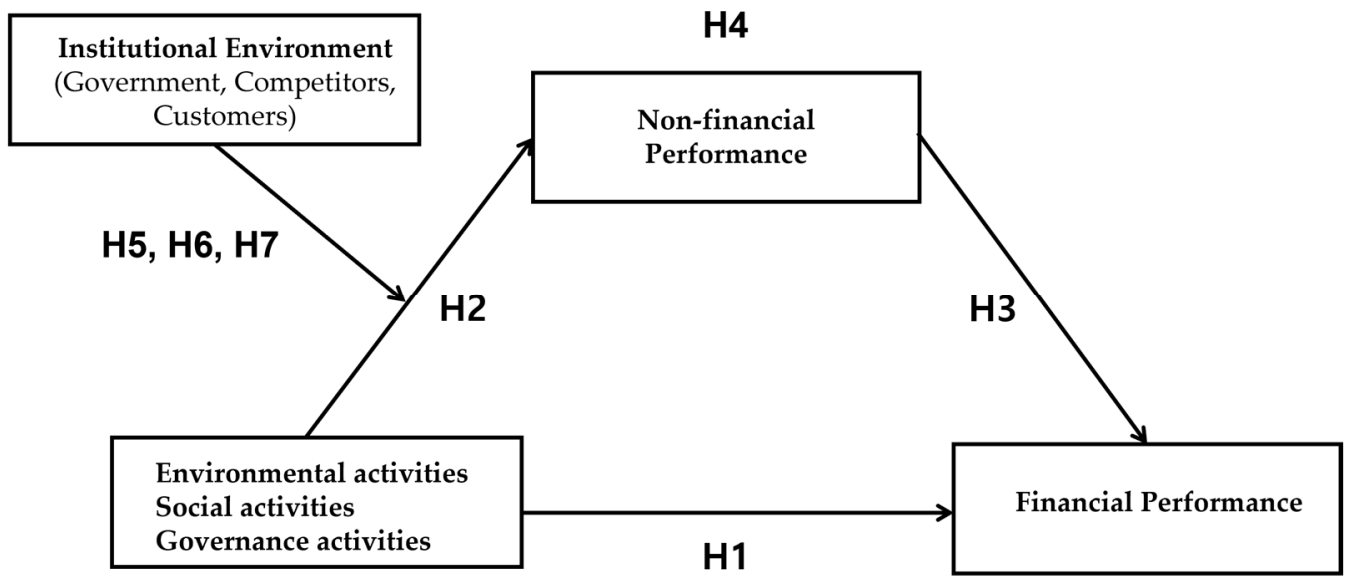

Figure 1. Research Model.

\section{Methodology}

\subsection{Sample and Data Collection}

The research model of this study is designed to explore the effect of the ESG activities of small and medium-sized Chinese manufacturers on their non-financial and financial performance. In general, the Chinese government as a major stakeholder strongly influences the ESG activities of large Chinese firms. Thus, there may be limitations in measuring the difference in ESG activities of large firms. On the contrary, the regulations and pressures of the Chinese government on ESG activities of small and medium-sized enterprises (SMEs) are relatively weak. Thus, there might be a significant difference in ESG 
activities of SMEs and their impact on performance. For this reason, we selected all the SMEs in the apparel/textile, machinery/equipment, chemical, computer/communication, and food/beverage industries from the Industrial Development Statistics of the National Economic Development Report provided by the Bureau of Statistics of China as research population. Of these industries, 2060 firms were chosen as our effective target population after firms with incorrect contact information and less than four years of operation were excluded.

A survey questionnaire was used to collect the data for our study. First, we drafted a questionnaire based on the literature. We then pretested the questionnaire on four senior SME executives in relevant industries to assess the clarity and appropriateness of the questions and revise the questionnaire based on their feedback. We also conducted a pilot test of the revised questionnaire on 10 senior SME executives in relevant industries to assess the distribution or pattern of their responses and then amended the questionnaire accordingly. We sent the finalized questionnaire by email to the CEOs of our target population three times at intervals of two weeks. Consequently, a total of 332 responses were retrieved, and 304 responses remained usable, with an effective response rate of $14.7 \%$; 28 substantially incomplete or insincerely filled-out surveys were excluded. Table 1 presents the descriptive statistics of sample firms.

Table 1. Results of confirmatory factor analysis $(n=304)$.

\begin{tabular}{|c|c|c|c|c|c|c|c|c|}
\hline Factors & Item & $\beta$ & $\begin{array}{c}\text { Factor } \\
\text { Loading }\end{array}$ & S.E. & $\begin{array}{l}\text { t-Value } \\
\text { (C.R.) }\end{array}$ & CR & AVE & $\begin{array}{c}\text { Cronbach's } \\
\alpha\end{array}$ \\
\hline \multirow{9}{*}{$\begin{array}{c}\text { Environmental } \\
\text { Activities }\end{array}$} & E1 & 1 & $0.763^{* * *}$ & & & \multirow{9}{*}{0.947} & \multirow{9}{*}{0.667} & \multirow{9}{*}{0.947} \\
\hline & E2 & 1.092 & $0.814^{* * *}$ & 0.071 & 15.290 & & & \\
\hline & E3 & 1.096 & $0.856^{* * *}$ & 0.067 & 16.272 & & & \\
\hline & $\mathrm{E} 4$ & 1.070 & $0.799^{* * *}$ & 0.072 & 14.959 & & & \\
\hline & E5 & 1.097 & $0.819^{* * *}$ & 0.071 & 15.404 & & & \\
\hline & E6 & 1.062 & $0.839^{* * *}$ & 0.067 & 15.878 & & & \\
\hline & E7 & 1.150 & $0.839^{* * *}$ & 0.073 & 15.858 & & & \\
\hline & E8 & 1.143 & $0.846^{* * *}$ & 0.071 & 16.024 & & & \\
\hline & E9 & 1.040 & $0.771^{* * *}$ & 0.073 & 14.312 & & & \\
\hline \multirow{7}{*}{ Social Activities } & S3 & 1 & $0.767^{* * *}$ & & & \multirow{7}{*}{0.921} & \multirow{7}{*}{0.625} & \multirow{7}{*}{0.921} \\
\hline & S4 & 1.051 & $0.801^{* * *}$ & 0.071 & 14.815 & & & \\
\hline & S5 & 1.073 & $0.793^{* * *}$ & 0.073 & 14.632 & & & \\
\hline & S6 & 1.003 & $0.790^{* * *}$ & 0.069 & 14.563 & & & \\
\hline & S7 & 1.059 & $0.819^{* * *}$ & 0.07 & 15.208 & & & \\
\hline & S8 & 1.03 & $0.777^{* * *}$ & 0.072 & 14.287 & & & \\
\hline & S9 & 0.929 & $0.788^{* * *}$ & 0.064 & 14.523 & & & \\
\hline \multirow{7}{*}{$\begin{array}{c}\text { Governance } \\
\text { Activities }\end{array}$} & G1 & 1 & $0.762^{* * *}$ & & & \multirow{7}{*}{0.923} & \multirow{7}{*}{0.631} & \multirow{7}{*}{0.922} \\
\hline & $\mathrm{G} 2$ & 1.168 & $0.825^{* * *}$ & 0.077 & 15.196 & & & \\
\hline & G3 & 1.076 & $0.822^{* * *}$ & 0.071 & 15.132 & & & \\
\hline & G4 & 0.967 & $0.799^{* * *}$ & 0.066 & 14.633 & & & \\
\hline & G5 & 1.04 & $0.785^{* * *}$ & 0.073 & 14.315 & & & \\
\hline & G6 & 1.169 & $0.783^{* * *}$ & 0.082 & 14.288 & & & \\
\hline & G7 & 1.099 & $0.784^{* * *}$ & 0.077 & 14.295 & & & \\
\hline \multirow{4}{*}{$\begin{array}{l}\text { Government } \\
\text { Pressure }\end{array}$} & GP1 & 1 & $0.794^{* * *}$ & & & \multirow{4}{*}{0.866} & \multirow{4}{*}{0.617} & \multirow{4}{*}{0.864} \\
\hline & GP2 & 1.02 & $0.790^{* * *}$ & 0.071 & 14.423 & & & \\
\hline & GP3 & 1.111 & $0.804^{* * *}$ & 0.075 & 14.737 & & & \\
\hline & GP4 & 1.078 & $0.753^{* * *}$ & 0.079 & 13.648 & & & \\
\hline \multirow{3}{*}{$\begin{array}{l}\text { Competitive } \\
\text { Pressure }\end{array}$} & CP1 & 1 & $0.818^{* * *}$ & & & \multirow{3}{*}{0.838} & \multirow{3}{*}{0.634} & \multirow{3}{*}{0.836} \\
\hline & $\mathrm{CP} 2$ & 0.995 & $0.821^{* * *}$ & 0.065 & 15.207 & & & \\
\hline & CP3 & 0.908 & $0.747^{* * *}$ & 0.066 & 13.655 & & & \\
\hline
\end{tabular}


Table 1. Cont.

\begin{tabular}{|c|c|c|c|c|c|c|c|c|}
\hline Factors & Item & $\beta$ & $\begin{array}{l}\text { Factor } \\
\text { Loading }\end{array}$ & S.E. & $\begin{array}{l}\text { t-Value } \\
\text { (C.R.) }\end{array}$ & CR & AVE & $\begin{array}{c}\text { Cronbach's } \\
\alpha\end{array}$ \\
\hline \multirow{3}{*}{$\begin{array}{l}\text { Customer } \\
\text { Pressure }\end{array}$} & CSP1 & 1 & $0.840^{* * *}$ & & & \multirow{3}{*}{0.872} & \multirow{3}{*}{0.694} & \multirow{3}{*}{0.871} \\
\hline & CSP2 & 1.047 & $0.873^{* * *}$ & 0.06 & 17.443 & & & \\
\hline & CSP3 & 0.924 & $0.784^{* * *}$ & 0.06 & 15.377 & & & \\
\hline \multirow{5}{*}{$\begin{array}{l}\text { Non-financial } \\
\text { Performance }\end{array}$} & N1 & 1 & $0.745^{* * *}$ & & & \multirow{5}{*}{0.883} & \multirow{5}{*}{0.603} & \multirow{5}{*}{0.883} \\
\hline & N2 & 1.077 & $0.793^{* * *}$ & 0.077 & 13.982 & & & \\
\hline & N3 & 0.937 & $0.739^{* * *}$ & 0.072 & 12.950 & & & \\
\hline & N4 & 1.124 & $0.830^{* * *}$ & 0.076 & 14.709 & & & \\
\hline & N5 & 1.042 & $0.772^{* * *}$ & 0.077 & 13.582 & & & \\
\hline \multirow{4}{*}{$\begin{array}{c}\text { Financial } \\
\text { Performance }\end{array}$} & F1 & 1 & $0.792^{* * *}$ & & & \multirow{4}{*}{0.859} & \multirow{4}{*}{0.604} & \multirow{4}{*}{0.858} \\
\hline & $\mathrm{F} 2$ & 1.066 & $0.755^{* * *}$ & 0.078 & 13.731 & & & \\
\hline & F3 & 1.101 & $0.753^{* * *}$ & 0.08 & 13.689 & & & \\
\hline & $\mathrm{F} 4$ & 1.163 & $0.807^{* * *}$ & 0.078 & 14.876 & & & \\
\hline
\end{tabular}

Note. $\mathrm{t}$-values for $n=304$ subsamples; $\mathrm{CR}$, composite reliability; $\mathrm{SE}$, standard error; AVE, average variance extracted; ${ }^{* * *} p<0.001$.

\subsection{Measurement}

All constructs were measured using multiple items. For each construct, a composite score was created by calculating the means of the items.

\subsubsection{Dependent Variable: Financial Performance}

Given that firms' financial performance is a multidimensional construct [95], we measured it in terms of four important dimensions. Following Zhao et al. [13] and Petti and Zhang [96], financial performance was measured by respondents' responses to (1) overall performance, (2) market share, (3) average growth rate of annual sales, and (4) and return on sales over the past two years $[13,96]$.

\subsubsection{Independent Variables: ESG Activities}

To measure the level of firms' ESG activities, we relied on a scale modified from Elkington [28], Petti and Zhang [96], Charan and Murty [97], and the ESG evaluation guidelines of the Korea Corporate Governance Service [98,99]. We asked the respondents to assess their perceived level of activities with each of the following items on a sevenpoint Likert scale ( 1 = "very low" to $7=$ "very high"). Specifically, the question items for firms' environmental activities were as follows. Activities in the environmental field were measured by the degree of (1) training to raise the awareness of environmental management and strengthening competence, (2) proposal of laws and regulations for environmental protection, (3) efforts to solve environmental problems, (4) production of products by using eco-friendly parts, (5) renewable energy use and energy saving, (6) carbon emissions and greenhouse gas emissions, (7) reduction of industrial waste, (8) establishment of the environmental performance management system, and (9) disclosure of significant matters and items related to environmental management activities.

The respondents' perceived level of social activities was then measured based on the following items: (1) welfare benefits for employees, (2) average turnover of employees, (3) establishment of personal information management policy for consumers, (4) efforts for customer satisfaction, (5) ethical business management, (6) compliance with laws and regulations related to social values, (7) efforts to create social value, (8) efforts for community development, and (9) participation in donation activities.

Finally, the respondents' perceived level of governance structure was measured by the following items: (1) guaranteed shareholder rights, (2) shareholder exercise of voting rights, (3) function of oversight by the board of directors, (4) board independence, (5) market disclosure of major matters, (6) disclosure of decision-making related to management 
change, and (7) establishment and publication of internal regulations on the exercise of shareholder rights.

\subsubsection{Mediating Variable: Non-Financial Performance}

To measure the level of firms' non-financial performance, we adopted the scales used by Zhao et al. [13] and Rothaermel and Alexandre [95]. We asked the respondents to indicate the perceived level of firms' non-financial performance with each of the following items on a seven-point Likert scale ( 1 = "very low" to $7=$ "very high"): (1) satisfaction level of employees, (2) external image, (3) stakeholder satisfaction level, (4) social reputation, and (5) the firm's brand value.

\subsubsection{Moderating Variable: Institutional Environment}

We relied on a scale adapted from $\mathrm{Li}$ [100] to measure the institutional environment. Specifically, the respondents were asked to indicate the perceived level of institutional pressure ( 1 = "very low" to 7 = "very high) with each of the following items: (1) government policy to strengthen CSR activities, (2) government engagement with CSR, (3) government interest in CSR activities, (4) utilization of CSR performance in the government's corporate reputation evaluation, (5) strategic importance of CSR when strengthening competitor's competitiveness, (6) competitors' interest in CSR activities, (7) degree of use of CSR performance comparison indicators among competitors, (8) the degree to which the production firm considers CSR when selecting a customer's product, (9) customer interest in CSR activities, and (10) the degree to which customers consider CSR performance to evaluate corporate reputation.

\subsubsection{Control Variables}

We included industry type, firm size, firm age, and research and development (R\&D) intensity as control variables in our model and controlled for their effects on non-financial and financial performance. As the type of industry is likely to influence firms' performance [95], we controlled for industry type with seven dummy-coded industries. Larger firms with more resources may have a higher investment capacity for their ESG activities than smaller firms with fewer resources [95]. Thus, firm size was controlled for and measured as the number of employees. Older firms can accumulate knowledge and experiences that may improve firm performance more than younger firms [101]; thus, we controlled for firm age effect measured by the number of years of operation. As R\&D investment can influence firm performance, we controlled for R\&D intensity in our study and measured it as $R \& D$ expenses as a percentage of sales [102].

\section{Analyses and Results}

\subsection{Method of Analyses}

We performed a confirmatory factor analysis using AMOS 25 to assess the reliability and validity of the measurements in our study. To examine the indirect effects presented in our mediation and moderated mediation models, we used PROCESS Macro for SPSS v. 3.14 because AMOS is not capable of modeling interactions of continuous latent variables. We applied the bootstrap confidence interval $(\mathrm{CI})$ approach by calculating the lower limit confidence interval (LLCI) and upper limit confidence interval (ULCI) of a 95\% bootstrap CI for indirect effects from 5000 bootstrap samples [103,104].

\subsection{Reliability and Validity}

A confirmatory factor analysis was performed to assess the reliability and validity of the measurements in our study. We first evaluated construct reliability using composite reliability (CR) and Cronbach's alpha. As shown in Table 1, the results demonstrate a high level of reliability that exceeds the recommended minimum value of 0.7 for both $C R$ and Cronbach's alpha [104]. Convergent and discriminant validity tests were conducted to assess the dimensionality of our constructs. As shown in Table 1, all the items were 
loaded clearly on their intended factors, with factor loadings greater than the cutoff value of 0.60 , and the average variance extracted (AVE) for each scale is higher than the threshold of 0.5. These results support the 8-factor solution with an adequate level of convergent validity [105]. We further evaluated the discriminant validity of our constructs using the inter-construct correlation matrix presented in Table 2. As shown in the matrix, the square root of the AVE for each factor is greater than any of its correlations with other factors, thus confirming satisfactory discriminant validity for all the factors [105]. Finally, as Table 1 demonstrates, the goodness-of-fit results for our CFA model reveals an acceptable level of fit, with $\chi 2=1083.133, \mathrm{df}=791, p<0.001, \chi 2 / \mathrm{df}=1.369, \mathrm{CFI}=0.968$, TLI $=0.965$, RMSEA $=$ $0.035[106,107]$.

Table 2. Descriptive statistics and correlation matrix $(n=304)$.

\begin{tabular}{|c|c|c|c|c|c|c|c|c|c|c|c|c|c|}
\hline & Mean & SD & 1 & 2 & 3 & 4 & 5 & 6 & 7 & 8 & 9 & 10 & 11 \\
\hline $\begin{array}{l}\text { 1. Financial } \\
\text { Performance }\end{array}$ & 5.28 & 0.87 & $(0.777)$ & $0.759 * *$ & $0.641^{* *}$ & $0.653^{* *}$ & $0.569 * *$ & $0.504^{* *}$ & $0.585^{* *}$ & $0.526^{* *}$ & & & \\
\hline $\begin{array}{l}\text { 2. Non-financial } \\
\text { Performance }\end{array}$ & 5.73 & 0.74 & $0.693^{* *}$ & $(0.777)$ & $0.761^{* *}$ & $0.745^{* *}$ & $0.663^{* *}$ & $0.606^{* *}$ & $0.666^{* *}$ & $0.618^{* *}$ & & & \\
\hline 3. Environmental & 5.77 & 0.75 & 0.576 ** & $0.697^{* *}$ & $(0.817)$ & $0.709 * *$ & $0.665^{* *}$ & $0.682 * *$ & $0.680 * *$ & 0.621 ** & & & \\
\hline 4. Social & 5.59 & 0.65 & 0.575 ** & $669 * *$ & $0.662 * *$ & $(0.791)$ & 0.627 ** & 0.554 ** & 0.651 ** & $0.597 * *$ & & & \\
\hline 5. Governance & 5.66 & 0.86 & $0.509^{* *}$ & $0.603 * *$ & $0.628 * *$ & $0.585^{* *}$ & $(0.795)$ & $0.607 * *$ & $0.558 * *$ & $0.519 * *$ & & & \\
\hline $\begin{array}{l}\text { 6. Government } \\
\text { Pressure }\end{array}$ & 5.82 & 0.69 & $0.433 * *$ & $0.536^{* *}$ & $0.622 * *$ & $0.497^{* *}$ & $0.549^{* *}$ & $(0.785)$ & 0.697 ** & $0.621 * *$ & & & \\
\hline $\begin{array}{l}\text { 7. Competitive } \\
\text { Pressure }\end{array}$ & 5.48 & 0.92 & $0.502 * *$ & $0.572 * *$ & $609 * *$ & $0.571 * *$ & $0.498^{* *}$ & $0.607^{* *}$ & $(0.796)$ & $0.696^{* *}$ & & & \\
\hline $\begin{array}{l}\text { 8. Customer } \\
\text { Pressure }\end{array}$ & 5.55 & 0.89 & $0.457^{* *}$ & $0.538^{* *}$ & $0.568^{* *}$ & $0.541 * *$ & $0.472 * *$ & $0.548^{* *}$ & $0.595 * *$ & (0.833) & & & \\
\hline 9. Firm size $(\log )$ & 6.27 & 1.11 & $0.184 * *$ & $0.222 * *$ & $0.150 * *$ & $0.200 * *$ & 0.089 & $0.133^{*}$ & $0.130 *$ & 0.035 & - & & \\
\hline 10. Firm age & 18.90 & 10.60 & 0.021 & 0.024 & -0.011 & -0.026 & -0.112 & -0.030 & -0.042 & $-0.122 *$ & $0.361 * *$ & - & \\
\hline 11. R\&D Intensity & 0.18 & 0.12 & $0.127 *$ & $0.201 * *$ & 0.103 & 0.061 & 0.061 & 0.045 & $0.119^{*}$ & 0.060 & 0.006 & 0.061 & - \\
\hline
\end{tabular}

Note: Numbers in parentheses on the diagonal are the square roots of the AVE values. Correlations among the constructs are reported above the diagonal; correlations among the composite scores are reported below the diagonal. SD: Standard Deviation; ${ }^{*} p<0.05 ;{ }^{* *} p<0.01$.

\subsection{Common Method Bias}

We checked and controlled for common method bias, as our study relied on a single respondent to measure the dependent and independent variables. First, as the data were collected through an online survey, we adopted a question randomization option to prevent potential common method bias in our study. Second, we conducted Harman's one-factor test with an unrotated factor solution to test for potential bias in our study [108]. The analysis derived a total of eight factors with an eigenvalue of 1.0 or higher with $35.31 \%$ of the variance explained by one factor, which is well below the maximum threshold of $50 \%$ [108].

To capture the common variance among all observed variables in the model, we finally performed a common latent factor (CLF) test by introducing a new latent variable to our CFA model such that all the observed items are related to it and compared the standardized regression weights of all items for the models with and without CLF. The differences are smaller than 0.2 , which confirms that common method bias does not affect the validity of this study [109].

\subsection{Tests of Hypotheses}

\subsubsection{Descriptive Statistics and Correlations}

The means, standard deviations, and correlations among the variables are presented in Table 2. As expected, all the correlations among the variables are significant and positive, which is consistent with the presumed direction of the relationships between the relevant variables presented in our hypotheses.

More specifically, as hypothesized in our models, the correlations are higher in the direct relationships between variables than the indirect ones. Inspection of the variance inflation factor (VIF) scores indicates no multicollinearity instances among any of the variables. The maximum VIF score in the models is 5.85, which is lower than the rule-ofthumb cutoff point of 10 . 


\subsubsection{Mediation Analyses}

Hierarchical Multiple Regression Analysis

Model 1 in Table 3 provides the results of the multiple regression analysis that examines the total effect of ESG activities on financial performance, including all the control variables. As expected, the coefficients for environmental $(b=0.270, p<0.001)$, social $(b=0.317, p<0.001$, and governance $(b=0.227, p<0.001)$ activities are all positive and significant, thereby supporting Hypotheses 1-1, 1-2, and 1-3. In terms of the relative magnitude of effects rather than significance, the comparisons of standardized regression coefficients reveal that social activities $(\beta=0.283)$ have the greatest influence on financial performance, followed by environmental $(\beta=0.238)$ and governance $(\beta=0.176)$ activities. Models 2 and 12 in Table 3 present the regression analysis results, based on the causal step approach proposed by Baron and Kenny [99] for the mediation effects of non-financial performance on the ESG activities-financial performance relationships. Model 2 reveals that environmental $(b=0.383, p<0.001)$, social $(b=0.349, p<0.001)$, and governance $(b=0.272, p<0.001)$ activities all have a significantly positive effect on non-financial performance. The relative magnitude of the effects on non-financial performance is shown as environmental $(\beta=0.328)$, social $(\beta=0.303)$, and governance $(\beta=0.205)$ activities, in descending order.

As a final step for mediation analysis, Model 12 shows that the effect of non-financial performance $(b=0.590, p<0.001)$ on financial performance is positive and significant after controlling for the effects of ESG activities on financial performance. However, the direct effects of environmental ( $b=0.044, p>0.05)$, social $(b=0.111, p>0.05)$, and governance $(b=0.067, p>0.05)$ activities on innovation performance are no longer statistically significant. These results suggest that non-financial performance completely mediates the relationship between ESG activities and firms' financial performance [110].

\section{Statistical Inference Test for Mediation Effects}

The causal step approach proposed by Baron and Kenny [99] neither formally quantifies the indirect effect nor requires any kind of inferential test. Therefore, to statistically estimate indirect effects in our mediation models, we calculated the LLCI and ULCI of a 95\% bootstrap CI for indirect effects from 5000 bootstrap samples [103].

Table 4 reports the results of the bootstrap significance test for total, indirect, and direct effects of ESG activities on financial performance, respectively. The total and indirect effects of environmental, social, and governance activities on financial performance are all significantly positive, whereas the direct effects of environmental, social, and governance activities are not significant (See Table 4). These results are consistent with the findings of the hierarchical multiple regression analysis. Therefore, Hypotheses 4-1, 4-2, and 4-3 are finally supported, thereby suggesting that pursuing a high level of ESG activities positively affects firms' non-financial performance, which, in turn, leads to superior financial performance. 
Table 3. Hierarchical multiple regression for Financial and Non-financial performance $(n=304)$.

\begin{tabular}{|c|c|c|c|c|c|c|c|c|c|c|c|c|c|c|c|c|c|c|c|c|c|c|c|c|}
\hline \multirow{3}{*}{ Variables } & \multicolumn{2}{|c|}{$\begin{array}{c}\text { Financial } \\
\text { Performance }\end{array}$} & \multicolumn{20}{|c|}{$\begin{array}{l}\text { Non-Financial } \\
\text { Performance }\end{array}$} & \multicolumn{2}{|c|}{$\begin{array}{c}\text { Financial } \\
\text { Performance }\end{array}$} \\
\hline & \multicolumn{2}{|c|}{ M1 } & \multicolumn{2}{|c|}{ M2 } & \multicolumn{2}{|c|}{ M3 } & \multicolumn{2}{|c|}{ M4 } & \multicolumn{2}{|c|}{ M5 } & \multicolumn{2}{|c|}{ M6 } & \multicolumn{2}{|c|}{ M7 } & \multicolumn{2}{|c|}{ M8 } & \multicolumn{2}{|c|}{ м9 } & \multicolumn{2}{|c|}{ M10 } & \multicolumn{2}{|c|}{ M11 } & \multicolumn{2}{|c|}{ M12 } \\
\hline & в & SE & в & $\mathrm{SE}$ & в & $\mathrm{SE}$ & в & SE & в & SE & в & SE & в & SE & в & SE & в & SE & в & SE & в & SE & в & SE \\
\hline $\begin{array}{c}\text { Firm Age } \\
\text { Firm Size (log) }\end{array}$ & $\begin{array}{l}0.004 \\
0.049\end{array}$ & $\begin{array}{l}(0.004) \\
(0.037)\end{array}$ & $\begin{array}{l}0.003 \\
0.067\end{array}$ & $\begin{array}{l}(0.003) \\
(0.031)\end{array}$ & $\begin{array}{l}0.003 \\
0.065 \text { * }\end{array}$ & $\begin{array}{l}(0.003) \\
(0.031)\end{array}$ & $\begin{array}{l}0.003 \\
0.063^{*}\end{array}$ & $\begin{array}{l}(0.003) \\
(0.031)\end{array}$ & $\begin{array}{l}0.003 \\
0.064 \text { * }\end{array}$ & $\begin{array}{l}(0.003) \\
(0.031)\end{array}$ & $\begin{array}{l}0.003 \\
0.066^{*}\end{array}$ & $\begin{array}{l}(0.003) \\
(0.031)\end{array}$ & $\begin{array}{l}0.003 \\
0.068^{*}\end{array}$ & $\begin{array}{l}(0.003) \\
(0.031)\end{array}$ & $\begin{array}{l}0.002 \\
0.070 \text { * }\end{array}$ & $\begin{array}{l}(0.003) \\
(0.031)\end{array}$ & $\begin{array}{l}0.003 \\
0.068^{*}\end{array}$ & $\begin{array}{l}(0.003) \\
(0.031)\end{array}$ & $\begin{array}{l}0.003 \\
0.071 \text { * }\end{array}$ & $\begin{array}{l}(0.003) \\
(0.003)\end{array}$ & $\begin{array}{l}0.003 \\
0.070^{*}\end{array}$ & $\begin{array}{l}(0.003) \\
(0.031)\end{array}$ & $\begin{array}{l}0.002 \\
0.009\end{array}$ & $\begin{array}{l}(0.003) \\
(0.032)\end{array}$ \\
\hline R\&D Intensity & 0.386 & $(0.297)$ & 0.888 & $(0.252)$ & 0.886 & $(0.249)$ & 0.891 & $(0.250)$ & 0.886 & $(0.251)$ & $0.827^{* *}$ & $(0.248)$ & $0.846^{* * *}$ & $(0.248)$ & 0.843 & $(0.031)$ & 0.887 & $(0.249)$ & 0.862 & $(0.248)$ & $0.884^{* *}$ & $(0.248)$ & -0.137 & $(0.263)$ \\
\hline Environmental (E) & $\underset{* * * *}{0.270}$ & $(0.074)$ & 0.383 & $(0.063)$ & -0.304 & $(0.280)$ & $\underset{\substack{0.343 \\
* * *}}{0.443}$ & $(0.067)$ & $\underset{\substack{0.339 \\
x * t+}}{0}$ & $(0.068)$ & -0.098 & $(0.174)$ & $\underset{* * *}{0.340}$ & $(0.065)$ & 0.332 & $(0.065)$ & 0.048 & $(0.225)$ & 0.334 & $(0.064)$ & 0.342 & $(0.065)$ & 0.044 & $(0.068)$ \\
\hline Social (S) & $\underset{* * * *}{0.317}$ & $(0.070)$ & 0.349 & $(0.059)$ & $\underset{* * *}{0.332}$ & $(0.059)$ & -0.122 & $(0.297)$ & $\underset{0.340}{0 * *+}$ & $(0.059)$ & $\underset{* * *+}{0.312}$ & $(0.060)$ & -0.133 & $(0.192)$ & $\underset{* * * *}{0.318}$ & $(0.060)$ & 0.311 & $(0.060)$ & -0.138 & $(0.223)$ & 0.319 & $(0.060)$ & 0.111 & $(0.064)$ \\
\hline Governance (G) & 0.227 & $(0.078)$ & 0.272 & $(0.059)$ & 0.237 & $(0.067)$ & 0.245 & $(0.067)$ & -0.026 & $(0.339)$ & 0.227 & $(0.066)$ & 0.244 & $(0.065)$ & -0.197 & $(0.260)$ & 0.253 & $(0.065)$ & 0.259 & $(0.065)$ & -0.200 & $(0.273)$ & 0.067 & $(0.069)$ \\
\hline $\begin{array}{l}\text { Non-financial } \\
\text { Performance }\end{array}$ & & & & & & & & & & & & & & & & & & & & & & & $\underset{* 0 * *}{0.590}$ & $(0.060)$ \\
\hline $\begin{array}{l}\text { Government } \\
\text { Pressure (GP) }\end{array}$ & & & & & $\underset{*}{-0.534}$ & $(0.274)$ & -0.345 & $(0.286)$ & -0.163 & $(0.325)$ & & & & & & & & & & & & & & \\
\hline $\mathrm{E} \times \mathrm{GP}$ & & & & & 0.049 & $(0.117)$ & & & & & & & & & & & & & & & & & & \\
\hline $\begin{array}{l}\mathrm{S} \times \mathrm{GP} \\
\mathrm{G} \times \mathrm{GP} \\
\end{array}$ & & & & & & & 0.081 & $(0.051)$ & 0.049 & $(0.059)$ & & & & & & & & & & & & & & \\
\hline $\begin{array}{l}\text { Competitive } \\
\text { Pressure (CP) }\end{array}$ & & & & & & & & & & & -0.344 & $(0.174)$ & -0.347 & $(0.190)$ & -0.350 & $(0.258)$ & & & & & & & & \\
\hline $\begin{array}{l}\mathrm{E} \times \mathrm{CP} \\
\mathrm{S} \times \mathrm{CP}\end{array}$ & & & & & & & & & & & $0.086 *$ & $(0.032)$ & & $(0.034)$ & & & & & & & & & & \\
\hline $\mathrm{G} \times \mathrm{CP}$ & & & & & & & & & & & & & & & 0.085 & $(0.047)$ & & & & & & & & \\
\hline $\begin{array}{c}\text { Customer } \\
\text { Pressure (CSP) }\end{array}$ & & & & & & & & & & & & & & & & & -0.186 & $(0.234)$ & -0.361 & $(0.234)$ & -0.337 & $(0.270)$ & & \\
\hline F-Statistics & \multirow{2}{*}{\multicolumn{2}{|c|}{$19.212^{* * * * *}$}} & \multirow{2}{*}{\multicolumn{2}{|c|}{$\begin{array}{c}39.625 \text { ***+4 } \\
0.620\end{array}$}} & \multirow{2}{*}{\multicolumn{2}{|c|}{$\begin{array}{c}35.288 * * * \\
0.631\end{array}$}} & \multirow{2}{*}{\multicolumn{2}{|c|}{$\begin{array}{l}34.699 * * \\
0.627\end{array}$}} & \multirow{2}{*}{\multicolumn{2}{|c|}{$\begin{array}{c}34.347 * * * * \\
0.625\end{array}$}} & \multirow{2}{*}{\multicolumn{2}{|c|}{$\begin{array}{c}36.170 * * * \\
0.637\end{array}$}} & \multirow{2}{*}{\multicolumn{2}{|c|}{$\begin{array}{c}35.949 * * * \\
0.635\end{array}$}} & & & \multirow{2}{*}{\multicolumn{2}{|c|}{$\begin{array}{c}35.441 * * * * \\
0.632\end{array}$}} & \multirow{2}{*}{\multicolumn{2}{|c|}{$\begin{array}{c}35.940 * * * \\
0.635\end{array}$}} & \multirow{2}{*}{\multicolumn{2}{|c|}{$\begin{array}{l}35.667 * * * * \\
0.63\end{array}$}} & & \\
\hline & & & & & & & & & & & & & & & & & & & & & & & & \\
\hline Adj. $R^{2}$ & & & & & & & & & 0. & & & & 0 & & & & & & & & & & & \\
\hline Changes in $R^{2}$ & & & & & & & & & & & & & & & & & & & & & & & & \\
\hline
\end{tabular}

Note: The table provides parameter estimates; standard errors are in parentheses. The estimated effects of industry dummies on dependent variables are not reported due to limitations of space. ${ }^{* * *} p<0.001,{ }^{* *} p<0.01,{ }^{*} p<0.05$. 
Table 4. Bootstrap significance test for mediating effects.

\begin{tabular}{|c|c|c|c|c|c|}
\hline Path & Effect & B & $\begin{array}{l}\text { Boot } \\
\text { (SE) }\end{array}$ & $\begin{array}{l}\text { Boot } \\
\text { LLCI }\end{array}$ & $\begin{array}{l}\text { Boot } \\
\text { ULCI }\end{array}$ \\
\hline \multirow{3}{*}{$\begin{array}{l}\text { Environmental activities- } \\
\text { Non-financial performance-Financial performance }\end{array}$} & Total effect & 0.270 & 0.074 & 0.125 & 0.416 \\
\hline & Direct effect & 0.044 & 0.068 & -0.089 & 0.179 \\
\hline & Indirect effect & 0.236 & 0.059 & 0.125 & 0.359 \\
\hline \multirow{3}{*}{$\begin{array}{l}\text { Social activities- } \\
\text { Non-financial performance-Financial performance }\end{array}$} & Total effect & 0.317 & 0.069 & 0.179 & 0.454 \\
\hline & Direct effect & 0.111 & 0.064 & -0.015 & 0.237 \\
\hline & Indirect effect & 0.206 & 0.047 & 0.105 & 0.293 \\
\hline \multirow{3}{*}{$\begin{array}{l}\text { Governance activities- } \\
\text { Non-financial performance-Financial performance }\end{array}$} & Total effect & 0.227 & 0.078 & 0.075 & 0.379 \\
\hline & Direct effect & 0.067 & 0.069 & -0.069 & 0.203 \\
\hline & Indirect effect & 0.160 & 0.051 & 0.069 & 0.270 \\
\hline
\end{tabular}

Note: Mediation analyses including all the control variables. LLCI: Low Limit Confidence Interval; ULCI: Upper Limit Confidence Interval. Bootstrap samples: 5000.

\subsubsection{Moderated Mediation Analysis}

Hypotheses 3 to 11 posit that the positive effect of ESG activities on firms' financial performance through non-financial performance varies depending on the level of three different institutional pressures, pointing to the need for a moderated mediation analysis [103]. If only one mediator exists in a model, the indirect effect is the product of two effects. In an analysis of moderated mediation, evidence of moderation of the indirect effect exists if one of the paths defining the indirect effect is moderated by a formal statistical test, and the other effect is statistically significant because the indirect effect is a product of two paths, one of which is moderated [103]. However, the evidence of moderated mediation generally implies merely that the indirect effect is statistically dependent on a moderator. Therefore, we need a follow-up inferential test to determine whether the conditional indirect effect is different from zero at certain specified values of a moderator to ascertain where the indirect effect is significant in the distribution of the moderator and where it is not [103].

Following Hayes [79] and Preacher et al.'s [111] statistical approach, we first examined how the positive effect of ESG activities on non-financial performance (mediator) varies depending on the level of different types of institutional pressure. As shown in Models 3 to 11 of Table 3, on the first path defining our mediation model, the interaction terms of "Environmental activities $\times$ Government pressure" $(b=0.964, p<0.001)$, "Environmental activities $\times$ Competitive pressure" $(\mathrm{b}=0.782, p<0.01)$, "Social activities $\times$ Competitive pressure" $(b=0.778, p<0.01)$, and "Social activities $\times$ Customer pressure" $(b=0.782$, $p<0.05$ ) have a significantly positive impact on firms' non-financial performance, thus improving the model fits significantly.

Additionally, we examined how the positive effect of environmental and social activities on non-financial performance varies depending on the level of pressure from the government, competitors, and customers, respectively, by applying the Johnson-Neyman (JN) technique [84]. Figures $2-5$ show the JN plot that presents the conditional effect of firms' environmental and social activities on non-financial performance at different moderator values. As shown in Figure 2, the point of transition (the value of government pressure) that demarcates the regions where the moderation effect of government pressure is significant or not is found to be 4.1(M). When $M>4.1$, the positive effect of environmental activities on non-financial performance is significant, but not significant when $M<4.1$. It shows the effect of environmental activities on non-financial performance is significantly positive among firms under high levels of pressure from government authorities $(M>4.1)$, but not significant among firms under relatively low levels of pressure from government authorities $(M<4.1)$. Figures 3 and 4 show that the impacts of firms' social and environmental activities on non-financial performance are significant only among those under competitive pressure above 3.8 and 3.2, respectively. Similarly, Figure 5 indicates that the impact of firms' social activities on non-financial performance is significant only among those facing a customer pressure higher than $3.7(\mathrm{M}>3.7)$. 


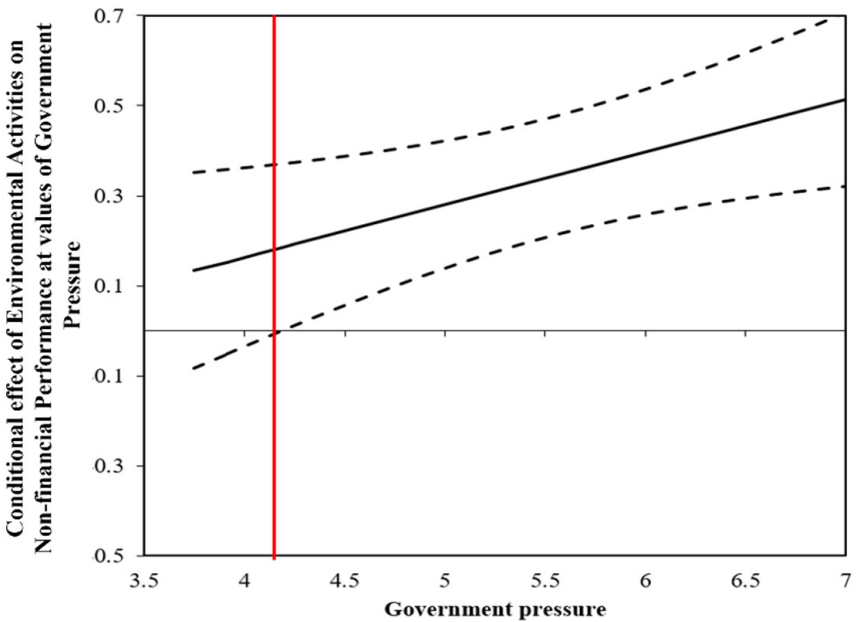

- - - 95\% CI Upper Limit

- Point Estimate

- - $-95 \%$ CI Lower Limi

Figure 2. Conditional effect of environmental activities on non-financial performance at values of government pressure.

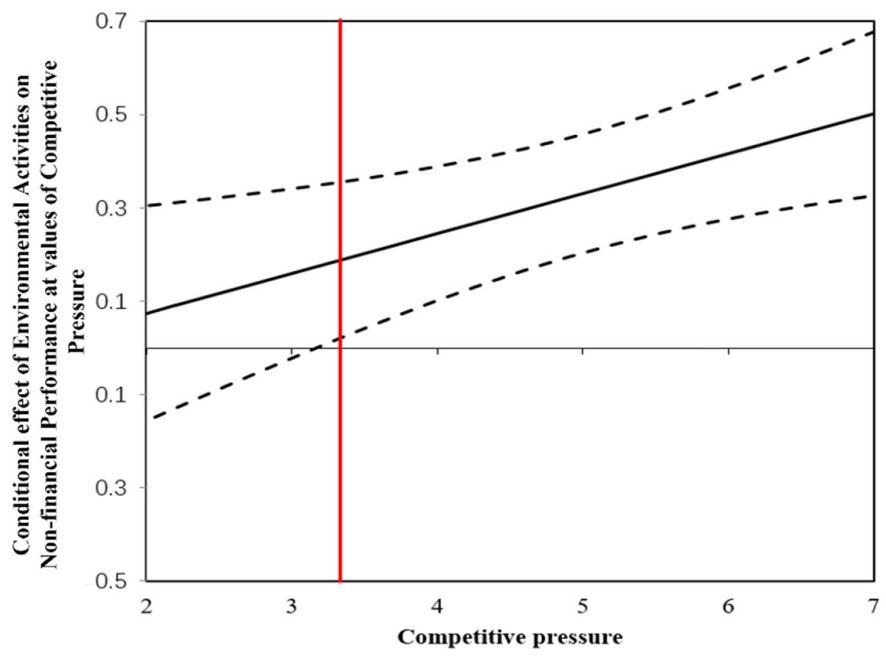

- - $95 \%$ CI Upper Limit

- Point Estimate

- - - 95\% CI Lower Limit

Figure 3. Conditional effect of environmental activities on non-financial performance at values of competitive pressure.

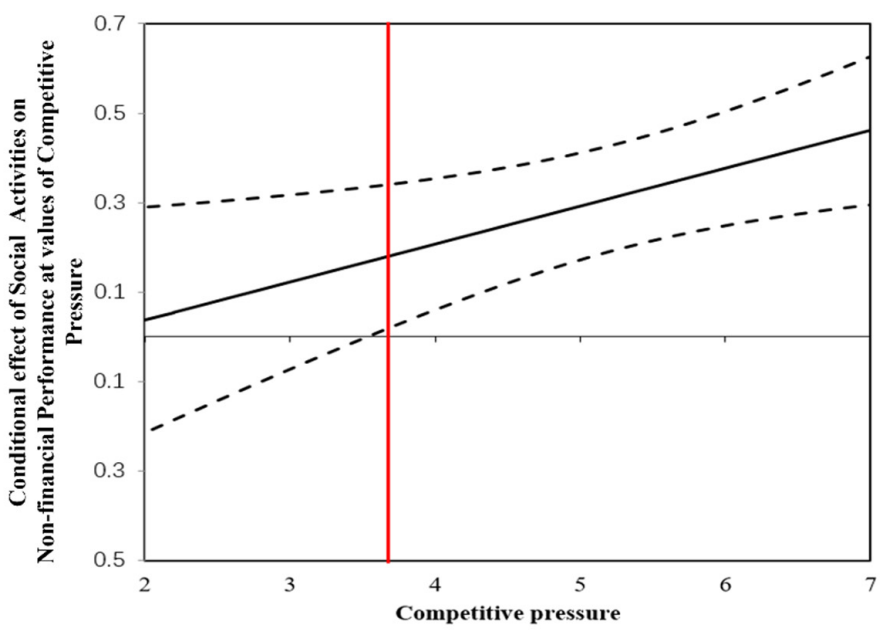

- - - 95\% CI Upper Limit

- Point Estimate

_ - - 95\% CI Lower Limit

Figure 4. Conditional effect of social activities on non-financial performance at values of competitive pressure. 


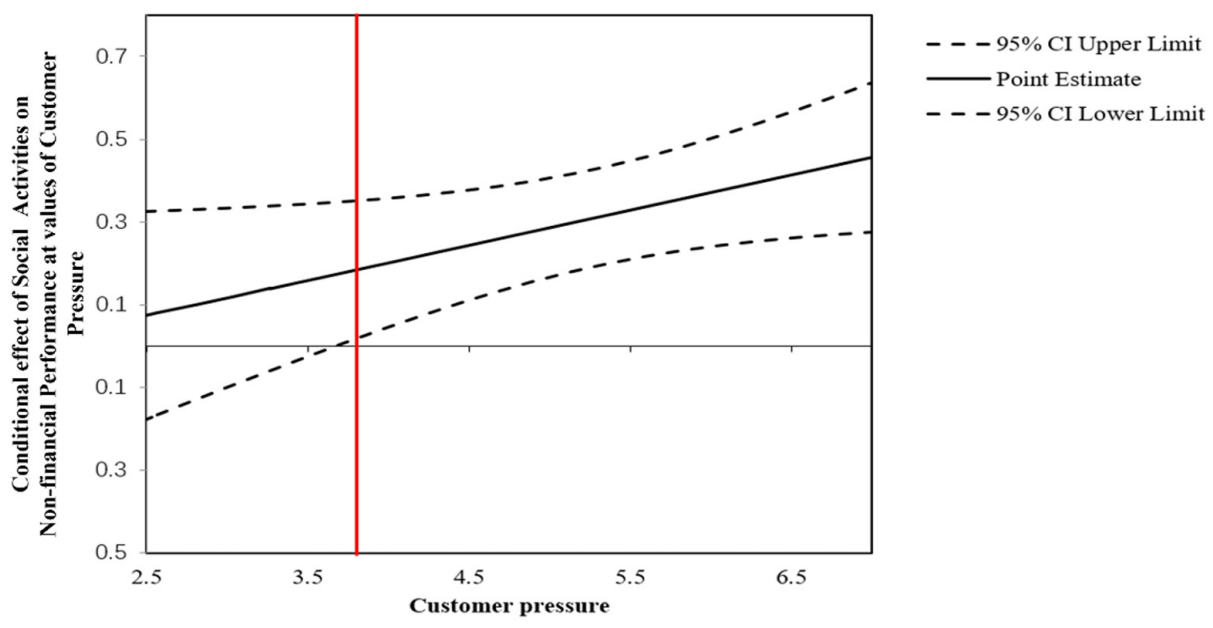

Figure 5. Conditional effect of social activities on non-financial performance at values of customer pressure.

Based on the results of both hierarchical multiple regression analyses and JN tests, we can conclude that the effect of the first paths of our model varies depending on institutional pressure levels. Specifically, the effects of environmental activities on non-financial performance are dependent on the pressure from the government and competitors, while those of social activities rely on the pressure from competitors and customers. In addition, as previously indicated in Model 11 of Table 3, the effect of non-financial performance on financial performance remains positive and significant after controlling for the effects of environmental and social activities on financial performance. Thus, we can finally conclude that the indirect effect of environmental activities on financial performance through non-financial performance is moderated by government and competitive pressure, and that the indirect effect of social activities on financial performance through non-financial performance is moderated by competitive and customer pressure.

Finally, we conducted an inferential test for the conditional indirect effect at various values of moderators $(+1 \mathrm{SD}$, mean, and $-1 \mathrm{SD})$ by estimating the conditional indirect effects at those values. As shown in Table 5, the indirect effects of both environmental and social activities on financial performance are all significantly positive at the three specified values of the moderators. In particular, the conditional indirect effect of environmental activities is stronger for firms scoring high $(+1 \mathrm{SD})$ in government pressure $(b=0.269$, $\mathrm{CI}=0.115 \sim 0.438)$ and competitive pressure $(\mathrm{b}=0.266, \mathrm{CI}=0.118 \sim 0.415)$ than for those scoring low $(-1 \mathrm{SD})$ in government pressure $(\mathrm{b}=0.174, \mathrm{CI}=0.072 \sim 0.316)$ and competitive pressure $(b=0.173, C I=0.080 \sim 0.316)$. Similarly, the conditional indirect effect of social activities on financial performance is more pronounced for those high in competitive pressure $(\mathrm{b}=0.242, \mathrm{CI}=0.121 \sim 0.351)$ and customer pressure $(\mathrm{b}=0.242, \mathrm{CI}=0.116 \sim 0.353)$ relative to those low in competitive pressure $(\mathrm{b}=0.149, \mathrm{CI}=0.023 \sim 0.259)$ and customer pressure $(\mathrm{b}=0.152, \mathrm{CI}=0.036 \sim 0.248)$. Based on the two-step approach to moderated mediation, we conclude that Hypotheses 5-1, 6-1, 6-2, and 7-2 are supported, while Hypotheses 5-2, 5-3, $6-3,7-1$, and 7-3 are not. These results suggest that even among firms pursuing high levels of ESG activities, those exposed to stronger institutional pressure are likely to yield better non-financial performance, which subsequently leads to superior financial performance. 
Table 5. Bootstrap significance test for the conditional indirect effect.

\begin{tabular}{|c|c|c|c|c|c|c|}
\hline Path & Mo & ator & $\begin{array}{l}\text { Conditional } \\
\text { Indirect Effects } \\
\text { (B) }\end{array}$ & Boot SE & $\begin{array}{l}\text { Boot } \\
\text { LLCI }\end{array}$ & $\begin{array}{l}\text { Boot } \\
\text { ULCI }\end{array}$ \\
\hline \multirow{3}{*}{$\begin{array}{l}\text { Environmental activities- } \\
\text { Non-financial performance-Financial } \\
\text { performance }\end{array}$} & \multirow{3}{*}{$\begin{array}{c}\text { Government } \\
\text { Pressures }\end{array}$} & $5.135(-1 \mathrm{SD})$ & 0.174 & 0.068 & 0.072 & 0.316 \\
\hline & & 5.825 (mean) & 0.222 & 0.065 & 0.108 & 0.359 \\
\hline & & $6.514(+1 \mathrm{SD})$ & 0.269 & 0.083 & 0.115 & 0.438 \\
\hline \multirow{9}{*}{$\begin{array}{c}\text { Social activities- } \\
\text { Non-financial performance-Financial } \\
\text { performance }\end{array}$} & \multirow{3}{*}{$\begin{array}{c}\text { Government } \\
\text { Pressures }\end{array}$} & $4.562(-1 \mathrm{SD})$ & 0.173 & 0.062 & 0.080 & 0.316 \\
\hline & & 5.482 (mean) & 0.219 & 0.059 & 0.117 & 0.352 \\
\hline & & $6.403(+1 \mathrm{SD})$ & 0.266 & 0.075 & 0.118 & 0.415 \\
\hline & \multirow{3}{*}{$\begin{array}{c}\text { Competitive } \\
\text { Pressures }\end{array}$} & $4.562(-1 \mathrm{SD})$ & 0.149 & 0.060 & 0.023 & 0.259 \\
\hline & & 5.482 (mean) & 0.195 & 0.050 & 0.091 & 0.287 \\
\hline & & $6.403(+1 \mathrm{SD})$ & 0.242 & 0.058 & 0.121 & 0.351 \\
\hline & \multirow{3}{*}{$\begin{array}{l}\text { Customer } \\
\text { Pressures }\end{array}$} & $4.657(-1 \mathrm{SD})$ & 0.152 & 0.053 & 0.036 & 0.248 \\
\hline & & 5.555 (mean) & 0.196 & 0.050 & 0.088 & 0.286 \\
\hline & & $6.454(+1 \mathrm{SD})$ & 0.242 & 0.060 & 0.116 & 0.353 \\
\hline
\end{tabular}

Note: Bootstrap samples: 5000.

\section{Conclusions and Discussion}

\subsection{Discussion}

Along with a mounting interest in corporate sustainability in both developed and emerging countries, firms have pursued sustainable management through ESG activities to survive amid rapid environmental changes, such as the coronavirus disease 2019 pandemic. With these environmental changes, research on the impact of sustainable management activities on financial performance has been increasing in recent years [5-18]. However, prior studies have primarily focused on examining the direct effect of sustainable management activities on financial performance. In contrast, surprisingly little research has been conducted on examining the mechanisms or conditions that influence the sustainable management activities-financial performance relationship [12]. This may be due to an implicit assumption in the literature that firms' sustainable management activities will unquestionably improve their financial performance. To fill the gap in the literature, we addressed the following three issues related to understanding the relationship between firms' ESG activities and their financial performance: (1) whether, (2) through what mechanisms, and (3) under what conditions firms' ESG activities have a positive impact on their financial performance.

Based on 304 SMEs in China, we first examined whether firms' ESG activities have a positive relationship with their financial performance (Table A1). Drawing on legitimacy theory and stakeholder theory, we suggested firms' non-financial performance as a mediating variable and examined its mediation effects on the relationship between ESG activities and financial performance. In addition, we further investigate how the effect of firms' ESG activities on financial performance through non-financial performance varies depending on institutional pressure levels in a unified moderated mediation model.

According to the results, the activities of Chinese manufacturers in each ESG field for sustainable management enhance financial performance. Moreover, our mediation analysis revealed that non-financial performance fully mediates the relationship between sustainable management activities and financial performance, as the relationship between ESG activities for sustainable management and financial performance becomes insignificant when non-financial performance is included as a mediator. In other words, ESG activities for sustainable management can significantly impact financial performance by improving non-financial performance, such as enhancing corporate reputation, image, employee satisfaction, and loyalty. The results imply that the direct relationship between firms' ESG activities and their financial performance shown in many existing studies may be spurious in nature. In addition, social activities have the most significant impact on financial performance, while environmental activities have the most significant impact on non-financial 
performance. These findings are consistent with those from prior research grounded in stakeholder theory that good image and reputation of stakeholders can create loyal customers for the firm's products and services, which serve to enhance the firm's value $[82,83]$. Finally, the moderated mediating effect analysis indicates that the relationship between "ESG activities-non-financial performance-financial performance" may vary greatly depending on institutional pressure levels. Specifically, the positive impact of environmental activities on financial performance through non-financial performance becomes stronger as government pressure and competitor pressure increase. The positive impact of social activities on financial performance through non-financial performance also becomes stronger as the pressures of competitors and customers increase. However, institutional pressure does not affect the positive impact of governance activities on financial performance through non-financial performance. These findings are in line with institutional theory literature suggesting that high levels of institutional pressure from the government, consumers, and competitors can be an important driving force to strengthen firms' sustainable management activities, which in turn enhance their reputation, legitimacy by building trust relationships with stakeholders [47-49,92-94].

\subsection{Implications}

The theoretical implications of this study are as follows: First, this study presents the relationship between sustainable management and ESG activities through a review of the literature in the field of sustainable management. It provides a theoretical background for subsequent studies that define and analyze the sustainability of firms from a more comprehensive perspective. Second, the results of this study indicate the importance of non-financial performance as an outcome variable of sustainable management activities. Most studies have focused on financial performance as an outcome variable of sustainable management activities. However, our results show that research that considers the relationship with non-financial performance is vital to strengthen the positive impact of sustainable management activities on performance. Finally, the results demonstrate that the relationship between ESG activities and corporate performance can vary depending on the type of institutional pressure. They emphasize the need to consider the impact of the institutional environment for further research in the field of sustainable management activities, thus motivating revitalizing convergence research in sustainable management and institutional theory.

The practical implications of this study are as follows: First, the importance of sustainable management activities is further emphasized in a rapidly changing global business environment. However, small and medium-sized firms, which do not have sufficient available resources, often experience the heavy burden of strengthening their ESG activities [18]. The results of this study imply that small and medium-sized firms can select more critical and urgent activities in consideration of their industry sector and firm characteristics, thereby focusing on them to improve both their non-financial and financial performance. Second, firms should enhance both short-term and long-term performance through sustainable management activities in a changing business environment. The results of this study show that firms can augment their financial performance by promoting ESG activities. Third, sustainability can be more efficiently reinforced by establishing and implementing differentiated action plans according to the level of institutional pressure in the market. Specifically, high pressure from the government requires strengthening social and governance activities. They need to be strengthened first in the face of high pressure from competitors. In response to customer pressure, environmental and governance improvement activities need to be prioritized to improve non-financial and financial performance according to the findings of the present study.

\subsection{Limitations and Future Research}

Notwithstanding these academic and practical implications, this study had the following limitations that can be addressed in future research. First, attention should be 
paid to the generalization of the study results owing to the distinct characteristics of the adopted study sample. This study was conducted on the listed manufacturers located in Beijing, China. Thus, China's social and cultural characteristics and the unique features of its manufacturing sector may have influenced the results. In future research, this limitation can be addressed by verifying the present analysis model for other countries, regions, and firms in the service industry. Second, there is the possibility of reverse causality that high corporate performance may become a motive to strengthen sustainable management activities. However, in this study, which employs survey data, the possibility of reverse causality cannot be controlled through the research model, which reflects the time difference between the two variables. This constraint can be supplemented through follow-up research using secondary panel data. Finally, most studies on sustainable management, including this one, have focused on analyzing the impact of sustainable management activities on performance. However, there is a lack of empirical studies on the internal and external antecedent factors that influence corporate sustainable management activities [112]. If future research on the antecedent factors that reinforce sustainable management activities, such as slack, is performed, additional value can be provided.

Author Contributions: Conceptualization: Y.L. and J.W.Y.; methodology: Y.L. and C.Y.K.; validation: J.W.Y.; formal analysis: Y.L. and C.Y.K.; investigation: J.W.Y.; resources: E.H.L.; writing—original draft preparation: Y.L. and C.Y.K.; writing-review and editing: J.W.Y.; visualization: E.H.L.; supervision, J.W.Y. All authors have read and agreed to the published version of the manuscript.

Funding: This paper was supported by Konkuk University in 2021, grant number 2021-A019-0221.

Institutional Review Board Statement: Not applicable.

Informed Consent Statement: Not applicable.

Data Availability Statement: Not applicable.

Conflicts of Interest: The authors declare no conflict of interest.

\section{Appendix A}

Table A1. Literature Reviews on the Relationship between ESG activities Financial Performance.

\begin{tabular}{|c|c|c|c|c|c|}
\hline Author(s) & Years & $\begin{array}{l}\text { Independent } \\
\text { Variable(s) }\end{array}$ & Dependent Variable(s) & Result & Sample \\
\hline Giese et al. [5]. & 2019 & $\begin{array}{l}\text { MSCI ESG Universal } \\
\text { Index }\end{array}$ & ESG Quintiles & + & 1600 stocks (2007-2017) \\
\hline Patrick Velte [6]. & 2019 & $\begin{array}{l}\text { ESG performance } \\
\text { E, S, G }\end{array}$ & ROA & $\begin{array}{c}+ \\
+++\end{array}$ & $\begin{array}{l}775 \text { firms in Germany } \\
(2010-2018)\end{array}$ \\
\hline Huang [7]. & 2021 & ESG activities & Performance & + & Review paper \\
\hline Patrick Velte [8]. & 2017 & ESG performance & $\begin{array}{l}\text { ROA } \\
\text { Tobin Q }\end{array}$ & $\begin{array}{l}+ \\
\mathrm{x}\end{array}$ & $\begin{array}{l}412 \text { firms in Germany } \\
(2010-2014)\end{array}$ \\
\hline Ortas et al. [9]. & 2015 & $\mathrm{E}, \mathrm{S}, \mathrm{G}$ index & $\begin{array}{l}\text { Tobin Q } \\
\text { ROA }\end{array}$ & $\begin{array}{l}++x \\
+x+\end{array}$ & 198 firms in UNGC (2008-2013) \\
\hline $\begin{array}{c}\text { Almeyda \& } \\
\text { Darmansya [10]. }\end{array}$ & 2019 & ESG scores & $\begin{array}{c}\text { ROA } \\
\text { ROC } \\
\text { Stock price } \\
\text { P/E }\end{array}$ & $\begin{array}{l}+ \\
+ \\
+ \\
x\end{array}$ & $\begin{array}{l}380 \text { listed firms in G7 countries } \\
\text { (2014-2018) }\end{array}$ \\
\hline Zhang et al. [11] & 2020 & $\begin{array}{l}\text { E, S, G (Disclosure } \\
\text { score) }\end{array}$ & Tobin Q & $x+-$ & $\begin{array}{l}952 \text { listed Chinese firms } \\
(2012-2018)\end{array}$ \\
\hline Friede et al. [12] & 2015 & E, S, G & Financial performance & $+-x$ & $\begin{array}{l}\text { Meta-analysis and vote-count } \\
\text { studies }\end{array}$ \\
\hline Zhao et al. [13] & 2018 & ESG & $\begin{array}{l}\text { Return on capital } \\
\text { employed (ROCE) }\end{array}$ & $\mathrm{x}$ & $\begin{array}{c}\text { Panel data from } 20 \text { Chinese } \\
\text { Listed power generation firms } \\
(2007-2016)\end{array}$ \\
\hline
\end{tabular}


Table A1. Cont.

\begin{tabular}{|c|c|c|c|c|c|}
\hline Author(s) & Years & $\begin{array}{l}\text { Independent } \\
\text { Variable(s) }\end{array}$ & Dependent Variable(s) & Result & Sample \\
\hline Xie et al. [14] & 2018 & ESG activities & Corporate efficiency & + & $\begin{array}{l}6631 \text { firms from } 74 \text { countries } \\
\text { (2015) }\end{array}$ \\
\hline Ahmad et al. [15] & 2021 & $\begin{array}{l}\text { ESG score (High) } \\
\text { ESG score (Low) }\end{array}$ & $\begin{array}{c}\text { Market value (MV), } \\
\text { Earnings per share (EPS) }\end{array}$ & $\begin{array}{l}+- \\
+-\end{array}$ & $\begin{array}{l}351 \text { firms in FTSE350 } \\
(2002-2018)\end{array}$ \\
\hline Dalal \& Thaker [16] & 2019 & ESG Index & $\begin{array}{c}\text { ROA } \\
\text { Tobin Q }\end{array}$ & $\begin{array}{l}+ \\
-\end{array}$ & $\begin{array}{l}65 \text { Indian firms listed on NSE } \\
100 \text { ESG Index (2015-2017) }\end{array}$ \\
\hline Deque-Grisales [17] & 2021 & $\begin{array}{c}\text { ESG score } \\
\text { E, S, G score }\end{array}$ & $\mathrm{ROA}$ & $\begin{array}{c}- \\
--- \\
\end{array}$ & $\begin{array}{l}104 \text { multinationals IN Latin } \\
\text { America between (2011-2015) }\end{array}$ \\
\hline Ruan \& Liu [18] & 2021 & ESG activities & Tobin Q & - & $\begin{array}{l}1372 \text { company-year } \\
\text { observations ESG rating in } \\
\text { China (2015-2019) }\end{array}$ \\
\hline
\end{tabular}

\section{References}

1. Adebanjo, D.; Teh, P.L.; Ahmed, P.K. The impact of external pressure and sustainable management practices on manufacturing performance and environmental outcomes. Int. J. Oper. Prod. Manag. 2016, 36, 995-1023. [CrossRef]

2. Rexhepi, G.; Kurtishi, S.; Bexheti, G. Corporate Social Responsibility (CSR) and Innovation-The Drivers of Business Growth? Procedia-Soc. Behav. Sci. 2013, 75, 532-541. [CrossRef]

3. Galpin, T.; Whitttington, J.L.; Bell, G. Is your sustainability strategy sustainable? Creating a culture of sustainability. Corp. Gov. 2015, 15, 1-17. [CrossRef]

4. Lampikoski, T.; Westerlund, M.; Rajala, R.; Möller, K. Green innovation games: Value-creation strategies for corporate sustainability. Calif. Manag. Rev. 2014, 57, 88-116. [CrossRef]

5. Giese, G.; Lee, L.E.; Melas, D.; Nagy, Z.; Nishikawa, L. Foundations of ESG investing: How ESG affects equity valuation, risk, and performance. J. Portf. Manag. 2019, 45, 69-83. [CrossRef]

6. Velte, P. Does CEO power moderate the link between ESG performance and financial performance? A focus on the German two-tier system. Manag. Res. Rev. 2019, 43, 497-520. [CrossRef]

7. Huang, D.Z. Environmental, social and governance (ESG) activity and firm performance: A review and consolidation. Acc. Financ. 2021, 61, 335-360. [CrossRef]

8. Velte, P. Does ESG performance have an impact on financial performance? Evidence from Germany. J. Glob. Responsib. 2017, 80, 169-178. [CrossRef]

9. Ortas, E.; Álvarez, I.; Garayar, A. The environmental, social, governance, and financial performance effects on companies that adopt the United Nations Global Compact. Sustainability 2015, 7, 1932-1956. [CrossRef]

10. Almeyda, R.; Darmansya, A. The Influence of Environmental, Social, and Governance (ESG) Disclosure on Firm Financial Performance. IPTEK J. Proc. Ser. 2019, 5, 278-290. [CrossRef]

11. Zhang, F.; Qin, X.; Liu, L. The Interaction Effect between ESG and Green Innovation and Its Impact on Firm Value from the Perspective of Information Disclosure. Sustainability 2020, 12, 1866. [CrossRef]

12. Friede, G.; Busch, T.; Bassen, A. ESG and financial performance: Aggregated evidence from more than 2000 empirical studies. $J$. Sustain. Financ. Invest. 2015, 5, 210-233. [CrossRef]

13. Zhao, C.; Guo, Y.; Yuan, J.; Wu, M.; Li, D.; Zhou, Y.; Kang, J. ESG and corporate financial performance: Empirical evidence from China's listed power generation companies. Sustainability 2018, 10, 2607. [CrossRef]

14. Xie, J.; Nozawa, W.; Yagi, M.; Fujii, H.; Managi, S. Do environmental, social, and governance activities improve corporate financial performance? Bus. Strateg. Environ. 2019, 28, 286-300. [CrossRef]

15. Ahmad, N.; Mobarek, A.; Roni, N.N. Revisiting the impact of ESG on financial performance of FTSE350 UK firms: Static and dynamic panel data analysis. Cogent. Bus. Manag. 2021, 8, 1900500. [CrossRef]

16. Dalal, K.K.; Thaker, N. ESG and corporate financial performance: A panel study of Indian companies. IUP J. Corp. Gov. 2019, 18, $44-59$.

17. Duque-Grisales, E.; Aguilera-Caracuel, J. Environmental, social and governance (ESG) scores and financial performance of multilatinas: Moderating effects of geographic international diversification and financial slack. J. Bus. Ethics 2021, 168, 315-334. [CrossRef]

18. Ruan, L.; Liu, H. Environmental, Social, Governance Activities and Firm Performance: Evidence from China. Sustainability 2021, 13, 767. [CrossRef]

19. Sepasi, S.; Rexhepi, G.; Rahdari, A. The changing prospects of corporate social responsibility in the decade of action: Do personal values matter? Corp. Soc. Responsib. Environ. Manag. 2021, 28, 138-152. [CrossRef]

20. Liu, X.; Anbumozhi, V. Determinant factors of corporate environmental information disclosure: An empirical study of Chinese listed companies. J. Clean. Prod. 2009, 17, 593-600. [CrossRef]

21. Lin, L.-W. Corporate Social Responsibility in China: Window Dressing or Structural Change? J. Int. Law. 2010, $28,64$. 
22. Oliver, C. Strategic responses to institutional processes. Acad. Manag. Rev. 1991, 16, 145-179. [CrossRef]

23. Tan, J.; Wang, L. MNC strategic responses to ethical pressure: An institutional logic perspective. J. Bus. Ethics 2011, 8, 373-390. [CrossRef]

24. Rahdari, A.; Sheehy, B.; Khan, H.Z.; Braendle, U.; Rexhepi, G.; Sepasi, S. Exploring global retailers' corporate social responsibility performance. Heliyon 2020, 6, E04644. [CrossRef]

25. Surroca, J.A.; Aguilera, R.V.; Desender, K.; Tribó, J.A. Is managerial entrenchment always bad and corporate social responsibility always good? A cross-national examination of their combined influence on shareholder value. Strateg. Manag. J. 2020, 41, 891-920. [CrossRef]

26. Bitektine, A.; Haack, P. The "macro" and the "micro" of legitimacy: Toward a multilevel theory of the legitimacy process. Acad. Manag. Rev. 2015, 40, 49-75. [CrossRef]

27. Meadows, D.H.; Randers, J.; Meadows, D.L.; Behrens III, W.W. The Limits to Growth (1972). In The Future of Nature: Documents of Global Change; Robin, L., Sörlin, S., Warde, P., Eds.; Yale University Press: New Haven, CT, USA, 2013; pp. 101-116.

28. Elkington, J. Partnerships from cannibals with forks: The triple bottom line of 21st-century business. Environ. Qual. Manag. 1998, 8, 37-51. [CrossRef]

29. Konrad, A.; Steurer, R.; Langer, M.E.; Martinuzzi, A. Empirical findings on business-society relations in Europe. J. Bus. Ethics 2006, 63, 89-105. [CrossRef]

30. Saam, J. Sustainability principles used to sustain the drive towards teaching excellence. J. Learn. Teach. 2015, 8, 1-12.

31. Elkington, J. Sustainable profits: Triple bottom line strategies for business and markets. Account. Tax. 2000, 71, 36-37.

32. Stead, J.G.; Stead, W.E. Building spiritual capabilities to sustain sustainability-based competitive advantages. J. Manag. Spiritual. Relig. 2014, 11, 143-158. [CrossRef]

33. Young, J.; Watt, A.; Nowicki, P.; Alard, D.; Clitherow, J.; Henle, K.; Richards, C. Towards sustainable land use: Identifying and managing the conflicts between human activities and biodiversity conservation in Europe. Biodivers. Conserv. 2005, 14, 1641-1661. [CrossRef]

34. Ben-Amar, W.; Chang, M.; McIlkenny, P. Board gender diversity and corporate response to sustainability initiatives: Evidence from the carbon disclosure project. J. Bus. Ethics 2017, 142, 369-383. [CrossRef]

35. Barnea, A.; Rubin, A. Corporate Social Responsibility as a Conflict between Shareholders. J. Bus. Ethics 2010, 97, 71-86. [CrossRef]

36. Deegan, C. Sustainability Accounting and Accountability, 2nd ed.; Routledge: London, UK, 2014.

37. Shocker, A.D.; Sethi, S.P. An approach to incorporating societal preferences in developing corporate action strategies. Calif. Manag. Rev. 1973, 15, 97-105. [CrossRef]

38. Mathews, M.R. Socially Responsible Accounting; Chapman Hall: London, UK, 1993.

39. Mahmud, M.T. Quest for a Single Theory to Explain Managerial Motivations for Sustainability Disclosures: Legitimacy Theory, Stakeholder Theory or Institutional Theory. Bull. Jpn. Assoc. Int. Account. Stud. 2020, 1, 135-159.

40. Phillips, R.A.; Barney, J.B.; Freeman, R.E.; Harrison, J.S. Stakeholder Theory; Cambridge University Press: New York, NY, USA, 2019.

41. Gray, R.; Owen, D.; Adams, C. Accounting \& Accountability: Changes and Challenges in Corporate Social and Environmental Reporting; Prentice Hall: London, UK, 1996.

42. Scott, W.R. Approaching adulthood: The maturing of institutional theory. Theory Soc. 2008, 37, 427-442. [CrossRef]

43. Bansal, P. Evolving sustainably: A longitudinal study of corporate sustainable development. Strateg. Manag. J. 2005, 26, 197-218. [CrossRef]

44. Suchman, M.C. Managing legitimacy: Strategic and institutional approaches. Acad. Manag. Rev. 1995, 20, 571-610. [CrossRef]

45. Colwell, S.R.; Joshi, A.W. Corporate ecological responsiveness: Antecedent effects of institutional pressure and top management commitment and their impact on organizational performance. Bus. Strateg. Environ. 2013, 22, 73-91. [CrossRef]

46. DiMaggio, P.J.; Powell, W.W. The iron cage revisited: Institutional isomorphism and collective rationality in organizational fields. Am. Sociol. Rev. 1983, 48, 147-160. [CrossRef]

47. Yang, H.; Lee, M.; Park, S. The impact of institutional pressures on green supply chain management and firm performance: Top management roles and social capital. Sustainability 2017, 9, 764.

48. Chu, Z.; Xu, J.; Lai, F.; Collins, B.J. Institutional theory and environmental pressures: The moderating effect of market uncertainty on innovation and firm performance. IEEE Trans. Eng. Manag. 2018, 65, 392-403. [CrossRef]

49. Phan, T.N.; Baird, K. The comprehensiveness of environmental management systems: The influence of institutional pressures and the impact on environmental performance. J. Environ. Manag. 2015, 160, 45-56. [CrossRef]

50. Deephouse, D.L. Does isomorphism legitimate? Acad. Manag. J. 1996, 39, 1024-1039. [CrossRef]

51. Kaplan, R.S.; Norton, D.P. The balanced scorecard: Measures that drive performance. Harv. Bus. Rev. 2005, 83, 71-79.

52. Mitra, S.; Chaya, A.K. Analyzing cost-effectiveness of organizations: The impact of information technology spending. J. Inf. Syst. 1996, 13, 29-57. [CrossRef]

53. Morgan, N.A.; Kaleka, A.; Katsikeas, C.S. Antecedents of export venture performance: A theoretical model and empirical assessment. J. Mark. 2004, 68, 90-108. [CrossRef]

54. Ittner, C.D.; Larcker, D.F. Quality strategy, strategic control systems, and organizational performance. Account. Org. Soc. 1997, 22, 293-314. [CrossRef] 
55. Phillips, D. Medical professional dominance and client dissatisfaction: A study of doctor-patient interaction and reported dissatisfaction with medical care among female patients at four hospitals in Trinidad and Tobago. Soc. Sci. Med. 1996, 42, 1419-1425. [CrossRef]

56. Hoque, Z.; James, W. Linking balanced scorecard measures to size and market factors: Impact on organizational performance. J. Manag. Acc. Res. 2000, 12, 1-17. [CrossRef]

57. Searcy, C. Corporate sustainability performance measurement systems: A review and research agenda. J. Bus. Ethics 2012, 107, 239-253. [CrossRef]

58. Walls, J.L.; Berrone, P.; Phan, P.H. Corporate governance and environmental performance: Is there really a link? Strateg. Manag. J. 2012, 33, 885-913. [CrossRef]

59. Hoque, Z. Linking environmental uncertainty to non-financial performance measures and performance: A research note. $\mathrm{Br}$. Account. Rev. 2005, 37, 471-481. [CrossRef]

60. Baker, W.E.; Sinkula, J.M. Environmental marketing strategy and firm performance: Effects on new product performance and market share. J. Acad. Mark. Sci. 2005, 33, 461-475. [CrossRef]

61. Albuhisi, A.M.; Abdallah, A.B. The impact of soft TQM on financial performance: The mediating roles of non-financial balanced scorecard perspectives. Int. J. Qual. Reliab. Manag. 2018, 35, 1360-1379. [CrossRef]

62. Delmas, M.A.; Pekovic, S. Environmental standards and labor productivity: Understanding the mechanisms that sustain sustainability. J. Organ. Behav. 2013, 34, 230-252. [CrossRef]

63. Nirino, N.; Santoro, G.; Miglietta, N.; Quaglia, R. Corporate controversies and company's financial performance: Exploring the moderating role of ESG practices. Technol. Forecast. Soc. 2021, 162, 120341. [CrossRef]

64. Siueia, T.T.; Wang, J.; Deladem, T.G. Corporate Social Responsibility and financial performance: A comparative study in the Sub-Saharan Africa banking sector. J. Clean. Prod. 2019, 226, 658-668. [CrossRef]

65. Porter, M.; Kramer, M. Creating shared value. Harv. Bus. Rev. 2011, 89, 62-77.

66. Hart, S.L. A natural-resource-based view of the firm. Acad. Manag. Rev. 1995, 20, 986-1014. [CrossRef]

67. Cho, S.Y.; Lee, C.; Pfeiffer, R.J., Jr. Corporate social responsibility performance and information asymmetry. J. Account. Public. Policy 2013, 32, 71-83. [CrossRef]

68. Wang, L.; Li, S.; Gao, S. Do greenhouse gas emissions affect financial performance? An empirical examination of Australian public firms. Bus. Strateg. Environ. 2014, 23, 505-519. [CrossRef]

69. Li, Y. Research on the performance measurement of green supply chain management in China. J. Sustain. Dev. 2011, 4, 101. [CrossRef]

70. Singh, S.K.; Del Giudice, M.; Chierici, R.; Graziano, D. Green innovation and environmental performance: The role of green transformational leadership and green human resource management. Technol. Forecast. Soc. Chang. 2020, 150, 119762. [CrossRef]

71. Dowell, G.; Hart, S.; Yeung, B. Do corporate global environmental standards create or destroy market value? Manag. Sci. 2000, 46, 1059-1074. [CrossRef]

72. Matthiesen, M.L.; Salzmann, A.J. Corporate social responsibility and firms' cost of equity: How does culture matter? Cross. Cult. Strateg. Manag. 2017, 24, 105-124. [CrossRef]

73. Dressler, M.; Paunović, I. Towards a conceptual framework for sustainable business models in the food and beverage industry: The case of German wineries. Br. Food. J. 2019, 122, 1421-1435. [CrossRef]

74. Brammer, S.; Millington, A. Does it pay to be different? An analysis of the relationship between corporate social and financial performance. Strateg. Manag. J. 2008, 29, 1325-1343. [CrossRef]

75. Allegrini, M.; Greco, G. Corporate boards, audit committees and voluntary disclosure: Evidence from Italian listed companies. J. Manag. Gov. 2013, 17, 187-216. [CrossRef]

76. Balachandran, B.; Faff, R. Corporate governance, firm value and risk: Past, present, and future. Pacific-Basin. Financ. J. 2015, 35, 1-12. [CrossRef]

77. Esteban-Sanchez, P.; de la Cuesta-Gonzalez, M.; Paredes-Gazquez, J.D. Corporate social performance and its relation with corporate financial performance: International evidence in the banking industry. J. Clean. Prod. 2017, 162, 1102-1110. [CrossRef]

78. Alsayegh, M.F.; Abdul Rahman, R.; Homayoun, S. Corporate economic, environmental, and social sustainability performance transformation through ESG disclosure. Sustainability 2020, 12, 3910. [CrossRef]

79. Freeman, R.E. Strategic Management: A Stakeholder Approach; Cambridge University Press: New York, NY, USA, 2010.

80. Ziek, P. Making sense of CSR communication. Corp. Soc. Responsib. Environ. Manag. 2009, 16, 137-145. [CrossRef]

81. Kimber, D.; Lipton, P. Corporate governance and business ethics in the Asia-Pacific region. Bus. Soc. 2005, 44, 178-210. [CrossRef]

82. Roberts, P.W.; Dowling, G.R. Corporate reputation and sustained superior financial performance. Strateg. Manag. J. 2002, 23, 1077-1093. [CrossRef]

83. Hossain, M.M.; Alamgir, M.; Alam, M. The mediating role of corporate governance and corporate image on the CSR-FP link: Evidence from a developing country. J. Gen. Manag. 2016, 41, 33-51. [CrossRef]

84. Birindelli, G.; Ferretti, P.; Intonti, M.; Iannuzzi, A.P. On the drivers of corporate social responsibility in banks: Evidence from an ethical rating model. J. Manag. Gov. 2015, 19, 303-340. [CrossRef]

85. Saeidi, S.P.; Sofian, S.; Saeidi, P.; Saeidi, S.P.; Saaeidi, S.A. How does corporate social responsibility contribute to firm financial performance? The mediating role of competitive advantage, reputation, and customer satisfaction. J. Bus. Res. 2015, 68, 341-350. [CrossRef] 
86. Ouni, Z.; Ben Mansour, J.; Arfaoui, S. Board/Executive Gender Diversity and Firm Financial Performance in Canada: The Mediating Role of Environmental, Social, and Governance (ESG) Orientation. Sustainability 2020, 12, 8386. [CrossRef]

87. Godfrey, P.C.; Merrill, C.B.; Hansen, J.M. The relationship between corporate social responsibility and shareholder value: An empirical test of the risk management hypothesis. Strateg. Manag. J. 2009, 30, 425-445. [CrossRef]

88. Erhemjamts, O.; Huang, K. Institutional ownership horizon, corporate social responsibility and shareholder value. J. Bus. Res. 2019, 105, 61-79. [CrossRef]

89. Pfeffer, J.; Salancik, G.R. The External Control of Organizations: A Resource Dependence Perspective; Stanford University Press: New York, NY, USA, 2003.

90. Rathert, N. Strategies of legitimation: MNEs and the adoption of CSR in response to host-country institutions. J. Int. Bus. Stud. 2016, 47, 858-879. [CrossRef]

91. Abrahamson, E.; Rosenkopf, L. Institutional and competitive bandwagons: Using mathematical modeling as a tool to explore innovation diffusion. Acad. Manag. Rev. 1993, 18, 487-517. [CrossRef]

92. Zhu, Q.; Geng, Y. Drivers and barriers of extended supply chain practices for energy saving and emission reduction among Chinese manufacturers. J. Clean. Prod. 2013, 40, 6-12. [CrossRef]

93. Zhang, Y.; Wei, Y.; Zhou, G. Promoting firms' energy-saving behavior: The role of institutional pressures, top management support and financial slack. Energy Policy 2018, 115, 230-238. [CrossRef]

94. Baines, A.; Langfield-Smith, K. Antecedents to management accounting change: A structural equation approach. Account. Org. Soc. 2003, 28, 675-698. [CrossRef]

95. Rothaermel, F.T.; Alexandre, M.T. Ambidexterity in technology sourcing: The moderating role of absorptive capacity. Organ. Sci. 2009, 20, 759-780. [CrossRef]

96. Petti, C.; Zhang, S. Factors influencing technological entrepreneurship capabilities: Towards an integrated research framework for Chinese enterprises. J. Technol. Manag. 2011, 6, 7-25. [CrossRef]

97. Charan, P.; Murty, L.S. Institutional pressure and the implementation of corporate environment practices: Examining the mediating role of absorptive capacity. J. Knowl. Manag. 2018, 22, 1367-3270.

98. Hess, D.; Rogovsky, N.; Dunfee, T.W. The next wave of corporate community involvement: Corporate social initiatives. Calif. Manag. Rev. 2002, 44, 110-125. [CrossRef]

99. Baron, R.M.; Kenny, D.A. The moderator-mediator variable distinction in social psychological research: Conceptual, strategic, and statistical considerations. J. Pers. Soc. Psychol. 1986, 51, 1173-1182. [CrossRef]

100. Li, Y. Environmental innovation practices and performance: Moderating effect of resource commitment. J. Clean. Prod. 2014, 66, 450-458. [CrossRef]

101. Lavie, D.; Stettner, U.; Tushman, M.L. Exploration and exploitation within and across organizations. Acad. Manag. Ann. 2010, 4 , 109-155. [CrossRef]

102. Liu, Y.; Kim, J.; Yoo, J. Intangible resources and internationalization for the innovation performance of Chinese high-tech firms. J. Open Innov. Technol. Mark. Complex. 2019, 5, 52. [CrossRef]

103. Preacher, K.J.; Hayes, A.F. Asymptotic and resampling strategies for assessing and comparing indirect effects in multiple mediator models. Behav. Res. Methods 2008, 40, 879-891. [CrossRef]

104. Hayes, A.F. Introduction to Mediation, Moderation, and Conditional Process Analysis: A Regression-Based Approach, 2nd ed.; Guilford Press: New York, NY, USA, 2017.

105. Nunnally, J.C. Psychometric Theory; McGraw-Hill: New York, NY, USA, 1967.

106. Fornell, C.; Larcker, D.F. Structural equation models with unobservable variables and measurement error: Algebra and statistics. J. Mark. Res. 1981, 18, 382-388. [CrossRef]

107. Bentler, P.M.; Chou, C.P. Practical issues in structural modeling. Sociol. Methods Res. 1987, 16, 78-117. [CrossRef]

108. Hair, J.; Anderson, R.; Tatham, R.; Black, W. Multivariate Data Analysis, 5th ed.; Prentice Hall: Upper Saddle River, NJ, USA, 1998.

109. Podsakoff, P.M.; MacKenzie, S.B.; Lee, J.Y.; Podsakoff, N.P. Common method biases in behavioral research: A critical review of the literature and recommended remedies. J. Appl. Psychol. 2003, 88, 879-903. [CrossRef]

110. Serrano Archimi, C.; Reynaud, E.; Yasin, H.M.; Bhatti, Z.A. How perceived corporate social responsibility affects employee cynicism: The mediating role of organizational trust. J. Bus. Ethics 2018, 151, 907-921. [CrossRef]

111. Preacher, K.J.; Rucker, D.D.; Hayes, A.F. Addressing Moderated Mediation Hypotheses: Theory, Methods, and Prescriptions. Multivar. Behav. Res. 2007, 42, 185-227. [CrossRef] [PubMed]

112. Laurett, R.; Paco, A.; Mainardes, E.W. Measuring sustainable development, its antecedents, barriers and consequences in agriculture: An exploratory factor analysis. Environ. Dev. 2021, 37, 100583. [CrossRef] 